\title{
Upper Proterozoic and Lower Cambrian rocks of the Sheeprock Mountains, Utah: Regional correlation and significance
}

NICHOLAS CHRISTIE-BLICK Exxon Production Research Co., P.O. Box 2189, Houston, Texas 77001

\section{ABSTRACT}

Apparently conformable upper Proterozoic and Lower Cambrian miogeoclinal rocks in the Sheeprock Mountains, Utah, attain a maximum thickness of at least $7,200 \mathrm{~m}$. The sequence begins at the base with phyllite, quartzite, glaciomarine diamictite, and shale deposited near the northern edge of a subsiding basin. These rocks are assigned to the Sheeprock Group $(2,700-4,300 \mathrm{~m})$. Overlying quartzitic rocks $(1,950-4,000 \mathrm{~m})$ are correlated with specific formations of the Brigham Group (Huntsville sequence). Revision of earlier accounts of the stratigraphy in the Sheeprock Mountains is suggested by the recognition of lowangle faults that attenuate the stratigraphic section.

Stratigraphic relations in the Sheeprock Mountains bear on regional correlation. The probable presence in the Deep Creek Range of two diamictite units separated by quartzite is reaffirmed. This sequence is grossly similar to that of the Sheeprock Mountains. It is suggested that the Caddy Canyon Quartzite (Brigham Group) interfingers to the south and west of the Sheeprock area with siltstone, shale, and some limestone. Possibly, no rocks exposed in the San Francisco Mountains and Canyon Range are older than the Caddy Canyon Quartzite. The McCoy Creek Group of western Utah and eastern Nevada is probably for the most part equivalent to the Caddy Canyon Quartzite. The Osceola Argillite (unit G, McCoy Creek Group) may be equivalent to the Inkom Formation, and it perhaps records a marine transgression that temporarily reduced the clastic supply. The correlation of the Mutual Formation of the platform sequence in the Wasatch Range to a lithologically similar unit in the miogeocline to the west remains the simplest interpretation, although the platform Mutual may be older than the unit of the same name in the miogeocline.

\section{INTRODUCTION}

In the Sheeprock Mountains and adjacent ranges (Figs. 1 and 2), structurally juxtaposed Proterozoic and Lower Cambrian rocks of greenschist metamorphic grade have a cumulative thickness of at least 7,200 $\mathrm{m}(23,600 \mathrm{ft})$. The upper Proterozoic stratigraphy established in northern Utah and southeastern Idaho by Crittenden and oth-

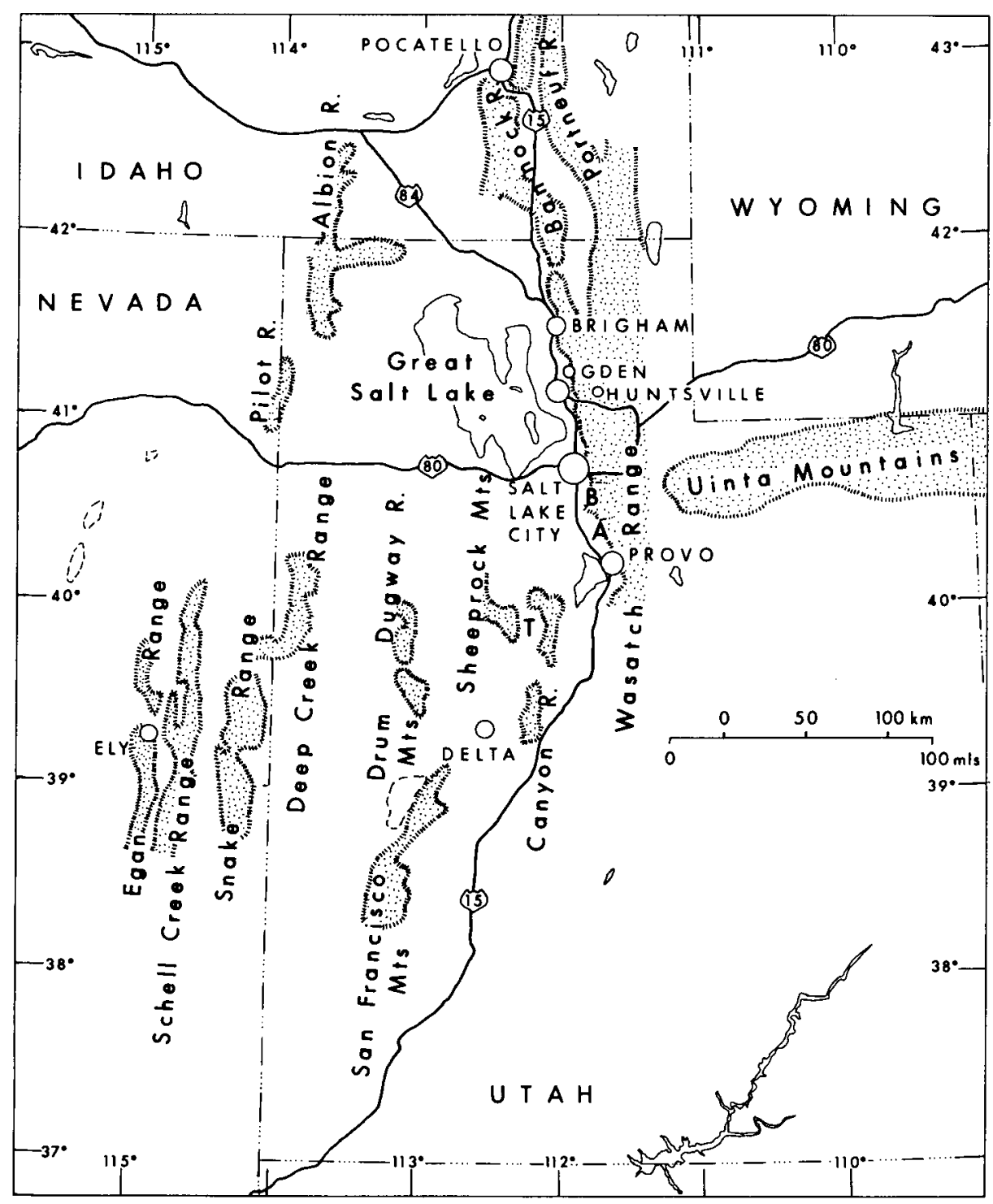

Figure 1. Location map for Utah and adjacent states indicating ranges mentioned in text. B, Big Cottonwood Canyon; A, American Fork Canyon; T, Tintic Valley.

Geological Society of America Bulletin, v. 93, p. 735-750, 15 figs., 1 table, August 1982. 


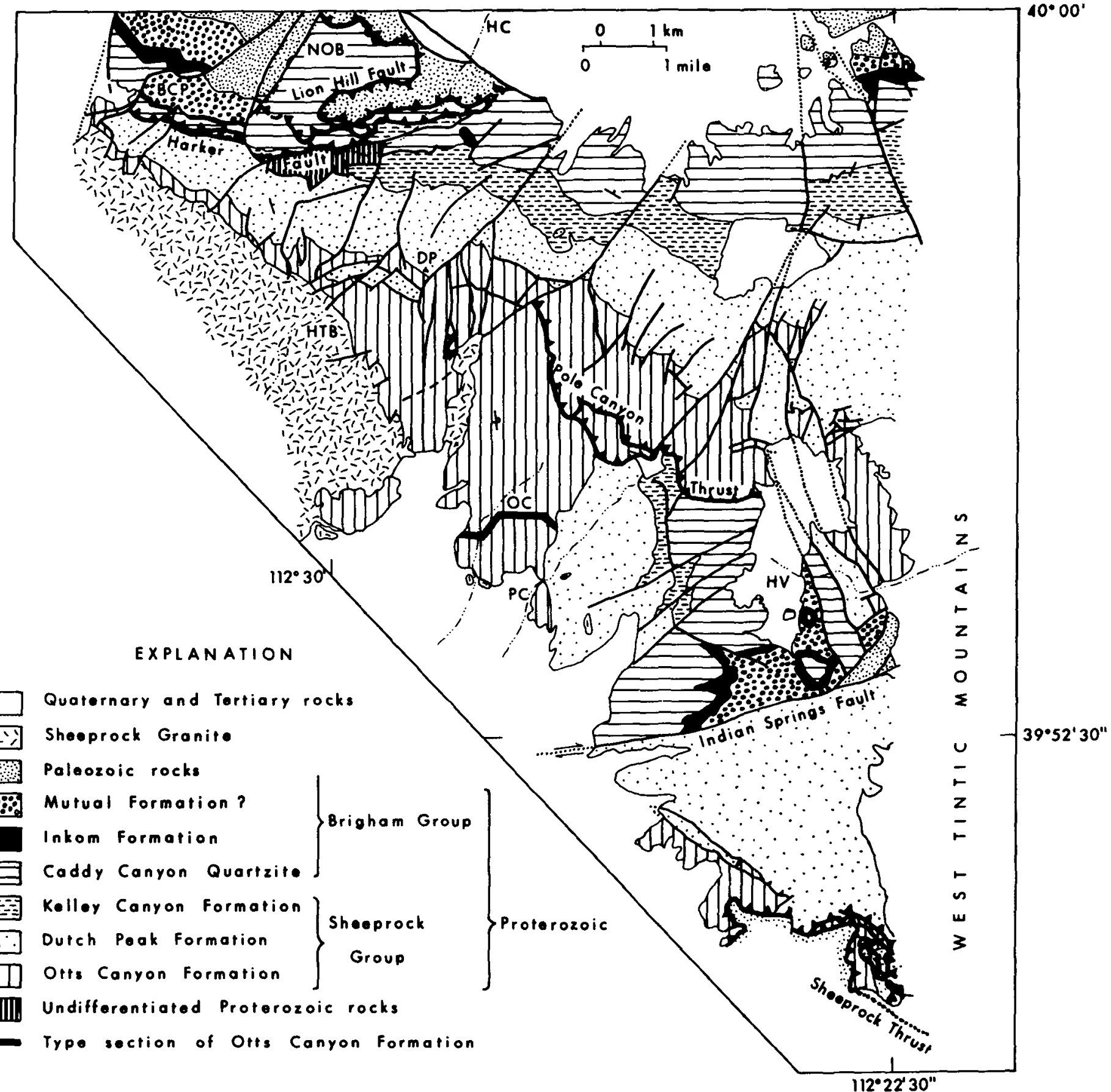

Figure 2. Simplified geologic map of Sheeprock Mountains from Blick (1979), Christie-Blick (unpub.), and Morris and Kopf (1970a, 1970b). NOB, North Oak Brush Canyon; HC, Harker Canyon; BCP, Black Crook Peak; DP, Dutch Peak; HTB, Hard-to-Beat Canyon; OC, Otts Canyon; PC, Pole Canyon; HV, Horse Valley.

ers (1971) is reasonably coherent for more than $350 \mathrm{~km}$ in a north-south direction, and specific formations are here identified in the Sheeprock Mountains in an apparently conformable sequence the hitherto had been suspected of being only loosely correlative (Fig. 3). The purpose of this paper is to describe the Proterozoic rocks of the Sheeprock Mountains and on the basis of stratigraphic and facies relations in that area to suggest revisions and extensions to earlier regional correlations. The rocks are particularly noteworthy for containing a thick section of diamictite that is probably glaciomarine. A brief interpretation of the rocks is suggested, with details to be published elsewhere.

Conclusions presented here are based largely on remapping at a scale of 1:24,000 of the Sheeprock Mountains north of latitude $39^{\circ} 54^{\prime}$ by Blick (1979) and of the southern part by Morris and Kopf (1970a, 1970b), together with brief visits to most of the other ranges shown in Figure 1.

\section{STRATIGRAPHY}

The Proterozoic sequence of the Sheeprock Mountains begins at the base with phyllite, a thin diamictite unit, and quartzite. These rocks are overlain by thick diamictite, shale, and several thousand metres of quartzitic rocks, the uppermost of which are of Early Cambrian age. This sequence is everywhere broken by faults and has been assembled from sections on several blocks (Figs. 2, 4, and 5). A major revision of pre- 


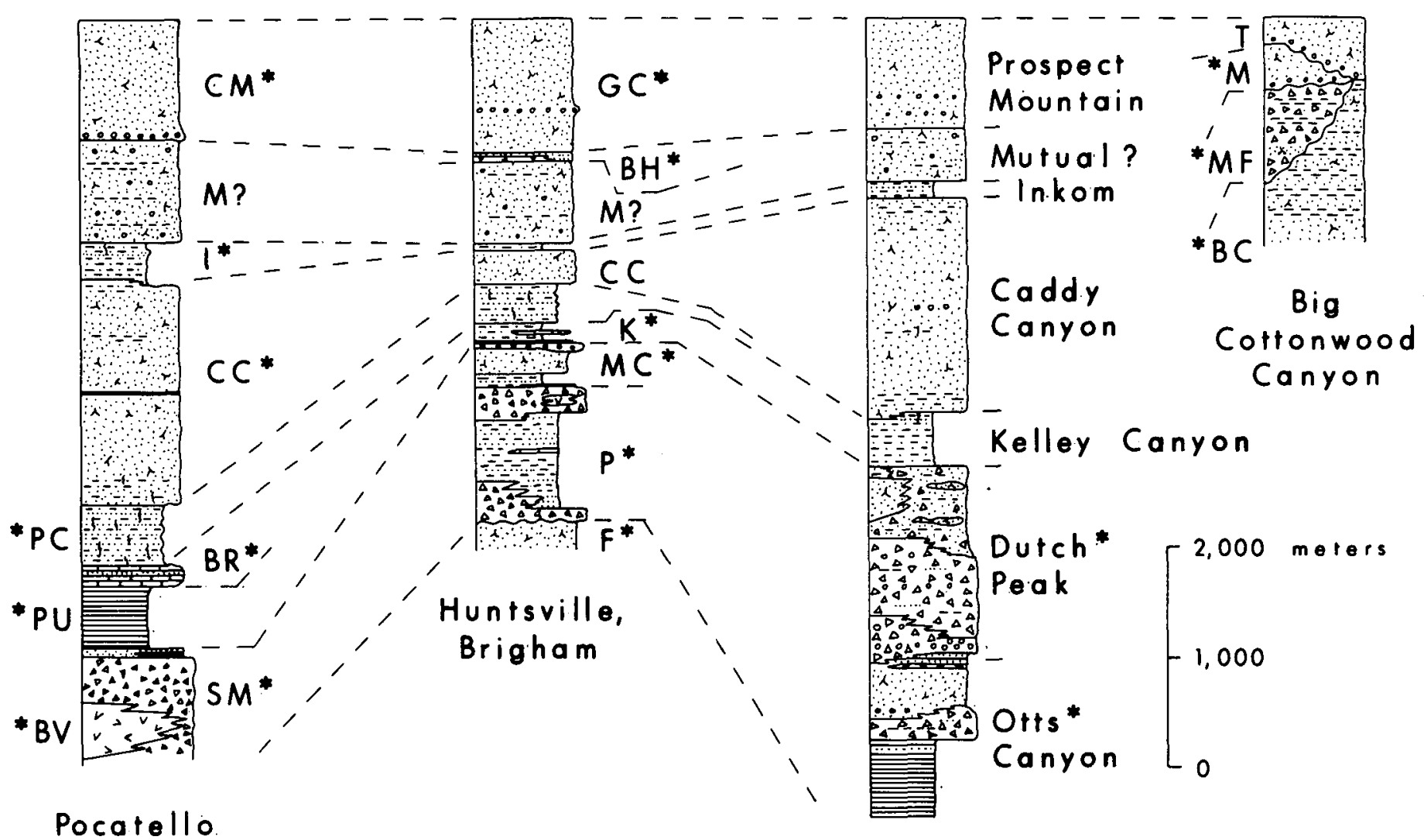

$\begin{array}{ll}\text { EXPLANATION } & \begin{array}{l}\text { Sheqprock } \\ \text { Mountains }\end{array} \\ & \end{array}$

Figure 3. Upper Proterozoic and Lower Cambrian stratigraphy near Pocatello, Idaho (modified from Trimble, 1976; Link and others, 1980), Huntsville and Brigham City, Utah (Crittenden and others, 1971; Sorensen and Crittenden, 1976), Sheeprock Mountains (this report), and Big Cottonwood Canyon, Wasatch Range, Utah (Crittenden and others, 1952). Stratigraphic units: CM, Camelback Mountain Quartzite; M, Mutual Formation; I, Inkom Formation; CC, Caddy Canyon Quartzite; PC, Papoose Creek Formation; BR, Blackrock Canyon Limestone; PU, SM, and BV, upper, Scout Mountain, and Bannock Volcanic members of Pocatello Formation; GC, Geertsen Canyon Quartzite; BH, Browns Hole Formation; K, Kelley Canyon Formation; MC, Maple Canyon Formation; P, formation of Perry Canyon; F, Facer Formation; T, Tintic Quartzite; MF, Mineral Fork Formation; BC, Big Cottonwood Formation. *, type locality of stratigraphic unit.

viously published interpretations of the stratigraphy above the diamictites is suggested by the recognition of low-angle faults that attenuate the stratigraphic section and by comparison with the stratigraphy elsewhere in northern Utah.

\section{Previous Work}

Early descriptions of rocks in the Sheeprock Mountains have been given by Loughlin and Heikes (in Butler and others, 1920), Eardley and Hatch (1940), Stringham (1942), and Gardner (1954). Cohenour (1959) divided the Proterozoic rocks into the Sheeprock "Series," including the medial Dutch Peak tillite, and the Mutual(?) Formation, between which he suggested there was a possible unconformity (Fig. 6). The same divisions were recognized by Groff (1959) in the adjacent West Tintic Mountains (Fig. 2). Harris (1958) studied a small area around Dutch Peak (DP in Fig. 2), where he defined the Ekker and Auts Canyon Formations, which he assigned to the Sheeprock Group. Further work shows, however, that his Auts Canyon Formation is overturned and partially equivalent to his Ekker Formation. Both are equivalent to the lower Sheeprock "Series" of Cohenour
(1959), and the Ekker includes part of the Dutch Peak "tillite." Morris and Kopf (1970a, 1970b) followed the nomenclature of Cohenour, although Morris and Kopf (1967) used both Sheeprock Formation and Dutch Peak Formation. Their implication was that the Dutch Peak represented a tongue of diamictite extending into a sequence of quartzite and shale (the Sheeprock Formation) grossly similar in lithologic character above and below the diamictite (H. T. Morris, 27 November 1978, written commun.). Blick (1976) referred to the Sheeprock Formation because the term "series" has time-stratigraphic connotations. 
Figure 4. Upper Proterozoic and Lower Cambrian stratigraphy of Sheeprock Mountains, showing lateral changes in thickness and facies between major structural units. Sections are composite for region between Otts Canyon and Horse Valley (beneath Pole Canyon Thrust), for northern flank of range (above Pole.Canyon Thrust), and for region between Black Crook Peak and North Oak Brush Canyon (above Harker Fault). Otts Canyon Formation divided into lower, middle, and upper members. Dutch Peak Formation divided into seven informal members: 1, laminite; 2, grit; 3, conglomerate; 4 , diamictite; 5 , graywacke; 6 , quartzite; 7 , argillite.

\section{Proposed Revisions to Stratigraphic Terminology}

Many stratigraphic units are mappable within the Proterozoic rocks. Following Harris (1958) and Armstrong (1968a), it is therefore suggested to raise Sheeprock to group status. In line with modern stratigraphic nomenclature, the Dutch Peak "tillite" becomes the Dutch Peak Formation. The lower Sheeprock interval is here designated the "Otts Canyon Formation," amended from Harris (1958) to conform with the different spelling of the geographic locality on the Dutch Peak Quadrangle map. The upper Sheeprock in the Sheeprock Mountains is tentatively correlated with the Kelley Canyon, Caddy Canyon, and Inkom Formations of Crittenden and others (1971). H. T. Morris (1978, personal commun.) has suggested to me that the latter strata may be sufficiently different in their type sections from post-Dutch Peak beds to be only questionably extended to the Sheeprock area. I have chosen, however, to emphasize the lithologic similarity and probable stratigraphic equivalence of Morris' upper Sheeprock division with the post-diamictite sequence at Pocatello, Idaho, and Huntsville, Utah (Crittenden and others, 1971).

At Huntsville, Utah (Fig. 1), the top of the Kelley Canyon Formation marks the base of the Brigham Group (Crittenden and others, 1971). In this paper, the Sheeprock Group is therefore restricted to include only the Otts Canyon, Dutch Peak, and Kelley Canyon Formations (Fig. 6). This usage also conforms most closely to the intent of Cohenour's stratigraphy in that northeast of Dutch Peak, rocks overlying the Dutch

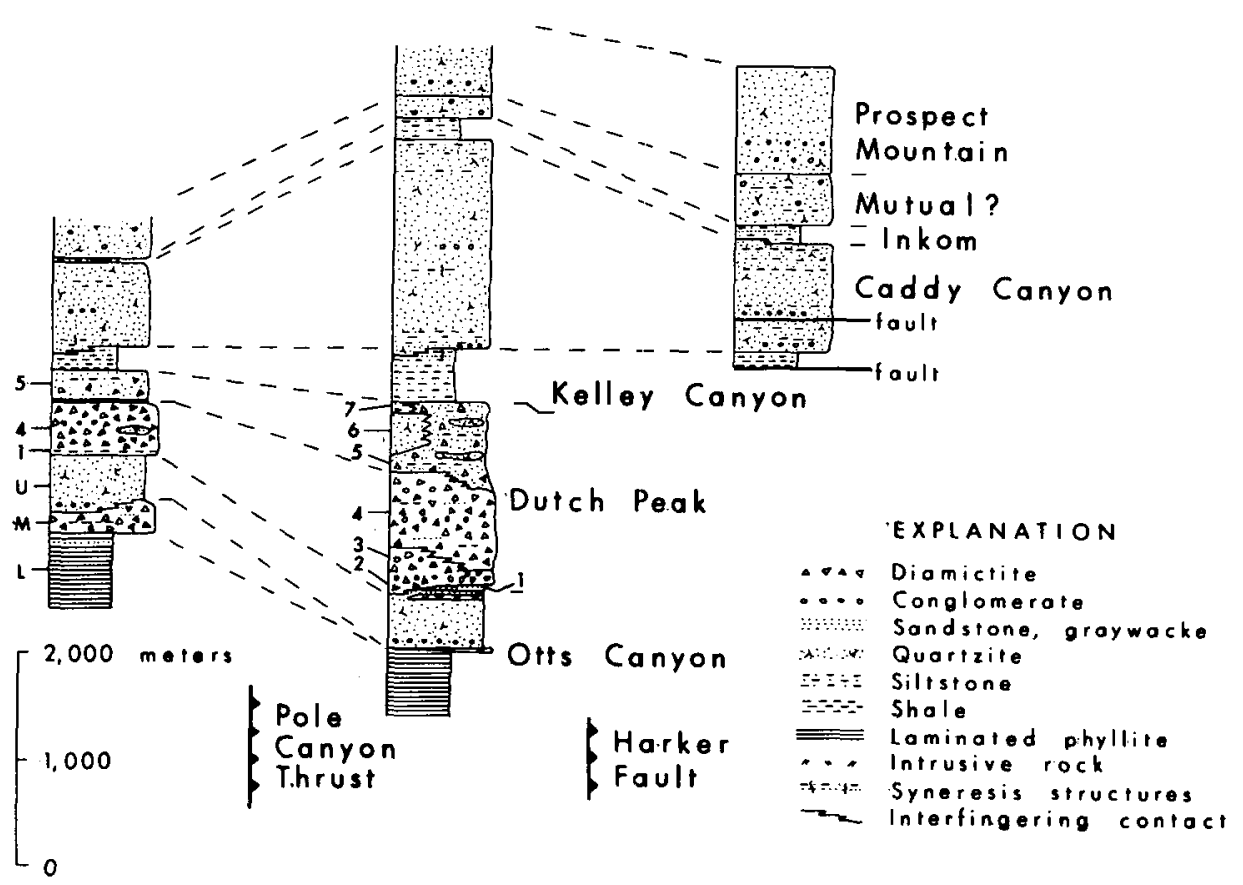

Figure 5. Lithologic description of upper Proterozoic and Lower Cambrian rocks of Sheeprock Mountains.

DESCRIPTION
Quartzite, white or light gray, fine- to medium-grained,
mature, slightly to moderately feldspathic; even parallel
laminations and ubiquitous cross-bedding; thin pebble
layers in lower part.


Peak "tillite" in its type section and mapped by Cohenour as upper Sheeprock "Series" are overlain by rocks here termed "Caddy Canyon Quartzite," although identified as possible Mutual Formation by Cohenour.

The lower argillite member of Cohenour's (1959) Mutual Formation. is reassigned to the upper part of the Inkom Formation (Fig. 6). However, the upper member of his Mutual closely resembles rocks at Huntsville which Crittenden and others (1971) have termed Mutual Formation and correlated with similar rocks in the central Wasatch Mountains (Crittenden and others, 1952). The use of the term "Mutual" is discussed further in a section below.

\section{Otts Canyon Formation}

The Otts Canyon Formation is made up of more than $2,000 \mathrm{~m}$ of pelite, diamictite,

Figure 5. (Continued).

\begin{tabular}{|c|c|c|c|c|c|}
\hline 峁 & 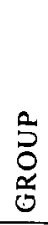 & 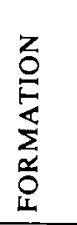 & 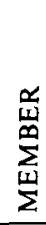 & 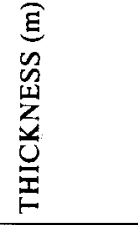 & DESCRIPTION \\
\hline \multirow{11}{*}{ 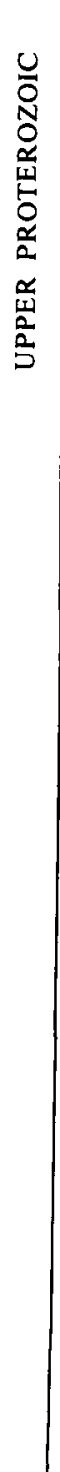 } & \multirow{11}{*}{ 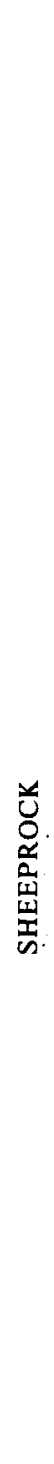 } & 学忌文 & & $155-575$ & $\begin{array}{l}\text { Shale and siltstone, olive-drab, tan, gray, or green, locally } \\
\text { micaceous and laminated; subordinate gray, green, and tan, } \\
\text { very fine- to fine-grained sandstone and quartzite particu- } \\
\text { larly in upper part, where generally wavy or contorted beds } \\
\text { are cut by sandstone dikelets. }\end{array}$ \\
\hline & & \multirow{7}{*}{ 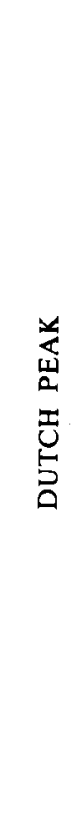 } & 7. & $0-250$ & Slate and argillite, liver-colored to black; locally laminated. \\
\hline & & & 6 & $0-300$ & $\begin{array}{l}\text { Quartzite, light gray to white, tan-weathering, fine- to } \\
\text { medium-grained; commonly laminated. }\end{array}$ \\
\hline & & & 5 & $300-900$ & $\begin{array}{l}\text { Graywacke and diamictite, olive green, grayish-green, } \\
\text { brown, or black, consisting of pebbles to boulders mainly of } \\
\text { quartzite, dolomite, and granite sparsely distributed in a } \\
\text { phyllitic sandy matrix; intercalated with lenses and beds of } \\
\text { gray, white, and tan fine- to medium-grained quartzite and } \\
\text { minor shale. }\end{array}$ \\
\hline & & & 4 & $0-900$ & $\begin{array}{l}\text { Diamictite, olive green, grayish-green, gray, or brown, con- } \\
\text { sisting of pebbles to boulders mainly of dolomite, quartzite, } \\
\text { and granite in a phyllitic matrix; intercalated with gray- } \\
\text { wacke, conglomerate, and siltstone. }\end{array}$ \\
\hline & & & 3 & $0-950$ & $\begin{array}{l}\text { Conglomerate and diamictite, dark gray, green, or brown, } \\
\text { consisting of pebbles to boulders mainly of granite, quartz- } \\
\text { ite, dolomite, and volcanic rocks in a feldspathic phyllitic } \\
\text { matrix; intercalated with. sandstone and siltstone. }\end{array}$ \\
\hline & & & 2 & $0-400$ & $\begin{array}{l}\text { Grit, maroon; interbedded with conglomerate, sandy dia- } \\
\text { mictite, graywacke, and sandstone. }\end{array}$ \\
\hline & & & 1 & $0-50$ & $\begin{array}{l}\text { Upper part (above Pole Canyon Thrust), distinctive metallic } \\
\text { blue-gray, fine-grained quartzite, commonly laminated. } \\
\text { Lower part, black, gray, or green, finely laminated siltstone } \\
\text { and very fine-grained sandstone. }\end{array}$ \\
\hline & & \multirow{3}{*}{ 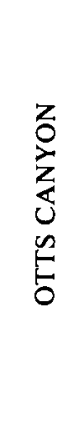 } & $\begin{array}{l}\frac{x}{w} \\
\frac{a}{a} \\
\frac{2}{b}\end{array}$ & $200-1,000$ & $\begin{array}{l}\text { Quartzite, gray to tan, fine- to. medium-grained, vitreous, } \\
\text { commonly laminated, rarely cross-bedded; subordinate } \\
\text { interbeds of conglomerate and grit, especially near base, and } \\
\text { graywacke, sandstone, slate, siltstone, and shale, especially } \\
\text { near top; diabase sills in upper part. }\end{array}$ \\
\hline & & & 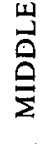 & $0-500$ & $\begin{array}{l}\text { Diamictite, gray, green, brown; or black, consisting of peb- } \\
\text { bles to boulders dominantly of quartzite in a phyllitic } \\
\text { matrix; intercalated with greenish-gray, fine- to medium- } \\
\text { grained quartzite and minor graywacke and slate. }\end{array}$ \\
\hline & & & $\stackrel{\substack{u \\
z}}{\underline{u}}$ & 700 & $\begin{array}{l}\text { Slate and phyllite, banded gray, silver gray, greenish-brown } \\
\text { to black; lower part contains fine- to very fine-grained sand- } \\
\text { stone interbeds. }\end{array}$ \\
\hline
\end{tabular}

and quartzite, intruded near the top by diabase sills. It is here divided into three informal members (Figs. 4 and.5). The name is taken from Otts Canyon on the south side of the Sheeprock Mountains (OC in Fig. 2 ). The type section extends from SWl/4 sec. 36, T. 10 S., R. 6 W., across Otts Canyon, into Pole Canyon (PC), NWI/4 sec. 31 , T. 10 S., R. 5 W., where structurally overturned beds are conformably overlain by the Dutch Peak Formation (Fig. 5). The base is not exposed.

The lower member consists of at least 700 $\mathrm{m}$ of gray to black slate and phyllite, commonly banded, with subordinate quartzite and grit. Between Otts Canyon and the western flank of the range, this unit has been converted to a hornfels by the Sheeprock Granite (Fig. 2) of Miocene'age (Armstrong, 1970; and quoted in Cohenour, 1970).

The middle member consists of 0 to 500 $\mathrm{m}$ of interbedded diamictite, quartzite, graywacke, grit, and slate of various hues of gray, green and black. This unit is not included in the Dutch Peak Formation (although of similar lithology)' principally to alter current stratigraphic terminology as little as possible, and also because it is thicker than $100 \mathrm{~m}$ only in the vicinity of Otts Canyon.

The upper member consists of about 200 $\mathrm{m}$ to more than $1,000 \mathrm{~m}$ of gray quartzite with subordinate interbeds of conglomerate, grit, graywacke, slate, siltstone; and shale, these most common toward the top of the unit. Rare angular fragments of black diamictite and slate in conglomerate confirm that diamictite stratigraphically underlies the upper member.

Diabase as thick as $150 \mathrm{~m}$ at or near the top of the Otts Canyon Formation is massive and non-vesicular. It contains no pillow structures and at one locality appears to have chilled upper and lower contacts. It is probably intrusive for the most part. Phenocrysts of albite, clinopyroxene, and ilmenomagnetite(?) partly altered to sphene are set in a groundmass of chlorite, actinolite, epidote, calcite, sphene, and sericite. The texture ranges from subophitic to intersertal. On Dutch Peak; boulder conglomerate near the base of the overlying Dutch Peak Formation contains angular diabase fragments as much as $60 \mathrm{~cm}$ across, making up an anomalous $17 \%$ of clasts greater than 1 $\mathrm{cm}$, and very likely derived from the underlying sills or from similar rocks at the same stratigraphic level. Intrusion probably occurred in latest Otts Canyon and/or earliest Dutch Peak time. 


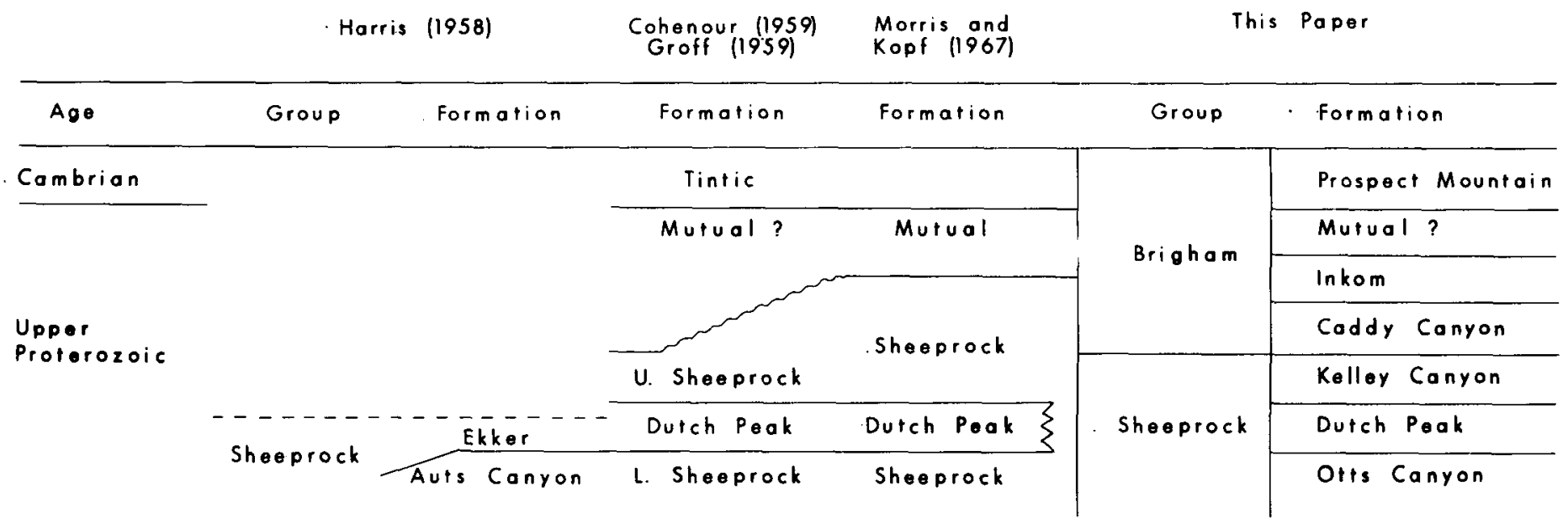

Figure 6. Published stratigraphic terminology of upper Proterozoic and Lower Cambrian rocks of Sheeprock Mountains, and proposed modifications.

\section{Dutch Peak Formation}

The Dutch Peak Formation consists of as much as $1,750 \mathrm{~m}$ of diamictite, conglomerate, graywacke, grit, sandstone, quartzite, siltstone, and shale, and it conformably overlies the Otts.Canyon Formation. It has been divided into seven informal members (Figs. 2 and 5), but these are lenticular, in places bounded by transitional contacts, and not all members occur together in any one section (Fig. 2). The best exposures are in the vicinity of Dutch Peak and Harker Canyon (DP and $\mathrm{HC}$ in Fig. 2), where the section is thickest and all members are exposed.

A characteristic feature of the Dutch Peak Formation is the presence of diamictite, much of it pebbly, but locally with cobbles and boulders as large as $3 \mathrm{~m}$. Clast abundance ranges from conglomeratic to very sparse. Clast types include plutonic rocks, gneiss, schist, quartzite, dolomite, vein quartz, basic and silicic volcanic rocks, and various intrabasinal sedimentary rocks. Diamictite matrix is chloritic, sandy to gritty, and texturally and mineralogically heterogeneous. A phyllitic cleavage is generally developed.

The lowest member (0-50 m thick) is a persistent, laminated siltstone and distinctive metallic blue-gray quartzite. Northwest of Hard-to-Beat Canyon (HTB in Fig. 2), this unit pinches out, and the lowermost member consists of $60-400 \mathrm{~m}$ of maroon grit and diamictite. The overlying conglomerate member $(0-950 \mathrm{~m})$ is characterized by thinly interbedded green or brown conglomerate and diamictite. The matrix is typically feldspathic and rich in metamorphic actinolite. The diamictite member $(0-900$ $\mathrm{m}$ ) is characterized by well-bedded, olive green to brown diamictite (Fig. 7). The overlying graywacke member (300-900 m), the most extensive unit of the Dutch Peak Formation, consists of olive green to black graywacke and diamictite, containing distinctive lenses and more continuous sheets of mature.quartzite (Fig. 8), with minor conglomerate, grit, sandstone, shale, and dolomite. South of the Indian Springs Fault (Fig. 2), this member constitutes the entire formation. In contrast to the underlying member, diamictite is more sandy, has a significant proportion of rounded grains, is less feldspathic, contains more sparsely distributed and smaller stones (small pebbles), has less well-defined bedding, and in the least deformed region on the northern flank of the range, it is less cleaved. The graywacke member becomes finer grained and less pebbly near the top, where it interfingers with shale of the overlying Kelley Canyon Formation. The graywacke member passes laterally into the quartzite member west of Harker Canyon (HC in Fig. 2). From 100 to $250 \mathrm{~m}$ of liver-colored or-black laminated slate occurs at the top of the Dutch Peak Formation in the vicinity of Black Crook Peak (BCP in Fig. 2), where it structurally underlies the gently dipping Harker Fault (new name). The relation of this member to the lithologically different Kelley Canyon Formation is unknown.

\section{Kelley Canyon Formation}

Rocks correlated with the Kelley Canyon Formation of Crittenden and others (1971) consist of 155 to $575 \mathrm{~m}$ of olive-drab to $\tan$ shale and siltstone, with subordinate sandstone and quartzite, particularly in the upper part. Some siltstone is laminated, but in many places bedding is difficult to distinguish from cleavage. The uppermost part of this unit in the northern Sheeprock Mountains locally contains wavy or contorted beds cut by sandstone dikelets, interpreted to be syneresis structures (Fig. 9). These are similar to the distinctive structures of the Papoose Creek Formation, which occurs at the same stratigraphic position near Pocatello, Idaho, and near Brigham City, Utah (Figs. 1 and 3; Crittenden and others, 1971; Trimble, 1976; Crittenden and Wallace, 1973).

\section{Lateral Relations in the Sheeprock Group}

Some notable lateral facies and thickness changes occur in all formations of the Sheeprock Group (Fig. 4). In the Pole Canyon Thrust plate (Figs. 2 and 10), individual members of the Otts Canyon and Dutch Peak Formations, and probably also the Kelley Canyon Formation, thin significantly toward the northwest, although the uppermost formation is cut out against the Harker Fault in Harker Canyon (HC in Fig. 2). In the Dutch Peak Formation, the conglomerate member becomes more quartzitic in the same direction and appears to interfinger with the underlying grit member. The diamictite member wedges out completely. The graywacke member interfingers with the quartzite member. Thickness variation is not due to flattening by the adjacent Sheeprock Granite (Fig. 2). Instead, the lateral relations in the Sheeprock Group are thought to indicate differential subsidence 
near the edge of a basin. Corroborating evidence is that the Otts Canyon diabase sills occur only in the thickest sequences, suggesting that subsidence was related to crustal extension and igneous intrusion. There is no direct evidence for growth faults in the rocks exposed, although the rapid thickness changes suggest draping over basement faults.

Beneath the Pole Canyon Thrust, diamictite of both the Otts Canyon and Dutch Peak Formations thickens markedly toward the south at the expense of the quartzite member of the Otts Canyon Formation, which interfingers with the underlying diamictite. The total thickness of the Sheeprock Group is less than above the thrust, primarily because of tectonic flattening, indicated by flattened pebbles in conglomerate and diamictite.

Stratigraphic relations above and below the Pole Canyon Thrust thus suggest the interfingering of relatively shallow water quartz-rich shelf sands on the north with immature diamictite in a deeper basin to the south. The orientation and configuration of the basin margin are, however, poorly constrained.

\section{Brigham Group}

The Brigham Group of northern Utah and southeastern Idaho, redefined by Crittenden and others (1971), is dominated by quartzitic rocks. The proposed correlation between the upper part of the Proterozoic sequence in the Sheeprock Mountains and the Brigham Group is based on sequence of rock types and bounding stratigraphic relations. It also depends upon conformable contacts inferred within the sequence, and on a reinterpretation of the structure of the northern Sheeprock Mountains, especially the recognition of low-angle faults that attenuate the stratigraphic section. Formations included within the Brigham Group of the Sheeprock Mountains are the Caddy Canyon Quartzite, the Inkom and Mutual Formations, and the Prospect Mountain Quartzite (Fig. 5).

\section{Caddy Canyon Quartzite}

Rocks here termed "Caddy Canyon Quartzite" consist of at least $2,000 \mathrm{~m}$ of white, gray, green, pink, tan, and brown quartzite with subordinate interbeds of olive-drab, liver-colored, and purple siltstone and shale, pink grit, and green conglomerate, which locally contains large

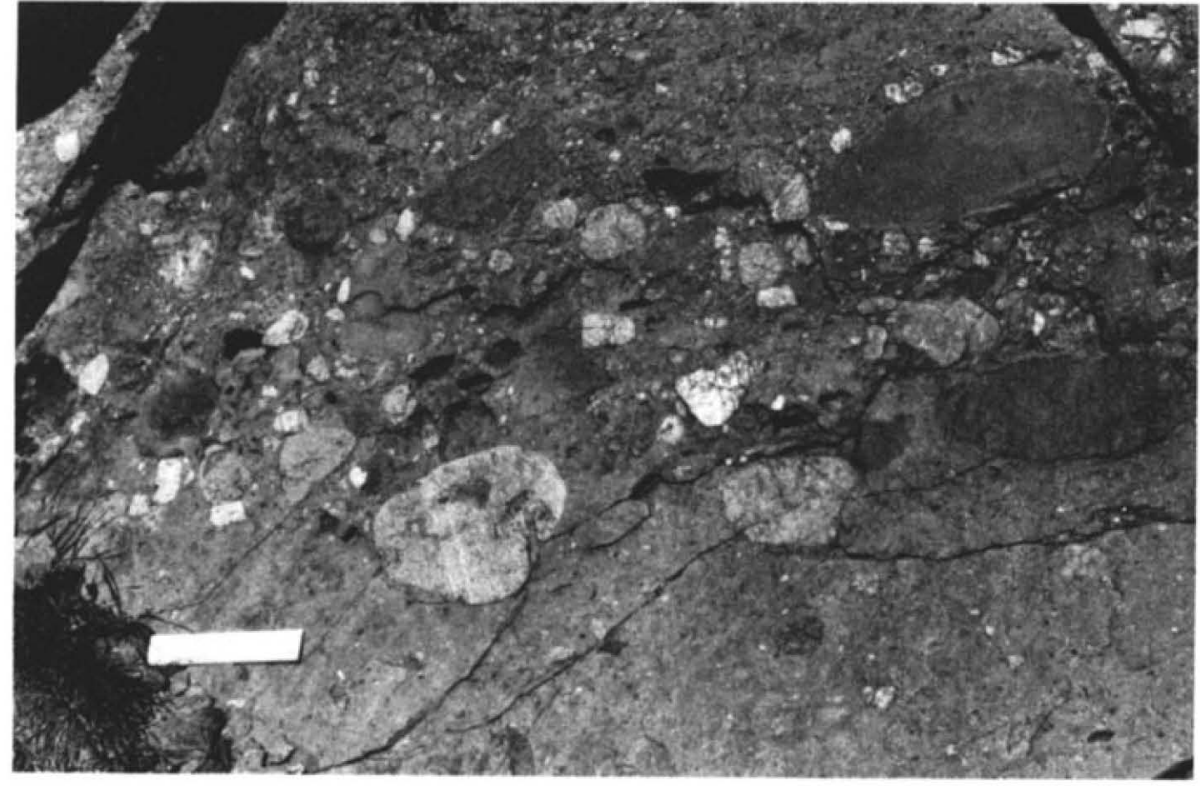

$\mathbf{A}$

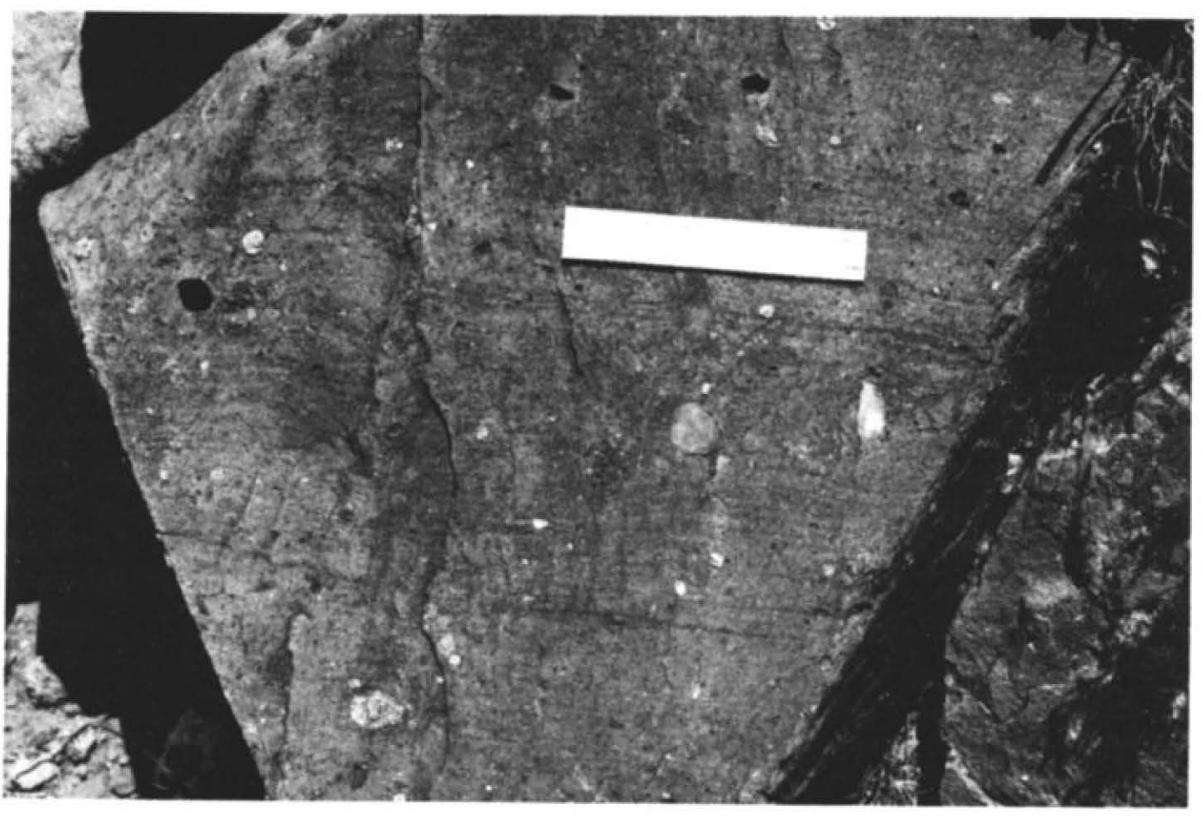

B

Figure 7. Bedding in diamictite of Dutch Peak Formation (diamictite member) in the vicinity of Dutch Peak. Scale is $15 \mathrm{~cm}$. A. Boulder conglomerate overlying diamictite. Stones are mainly dolomite (weathering out), quartzite, vein quartz, granite, and schist. B. Quartzite and granite pebbles in diffusely laminated graywacke.

angular fragments of intraformational siltstone. Siltstone interbeds occur mainly in the lower part of the formation and in the upper $300 \mathrm{~m}$ in the vicinity of Black Crook Peak (BCP in Fig. 2), suggesting conformable and transitional upper and lower contacts with finer-grained rocks. Several metres of purplish-brown intraformational conglomerate occurring in the base of the overlying Inkom Formation at the south end of Horse Valley (HV in Fig. 2) were interpreted by Groff (1959) to indicate subaerial conditions and local nondeposition, but this lithology of the Inkom is atypical in the Sheeprock Mountains and other ranges in western Utah and southern Idaho. Litho- 


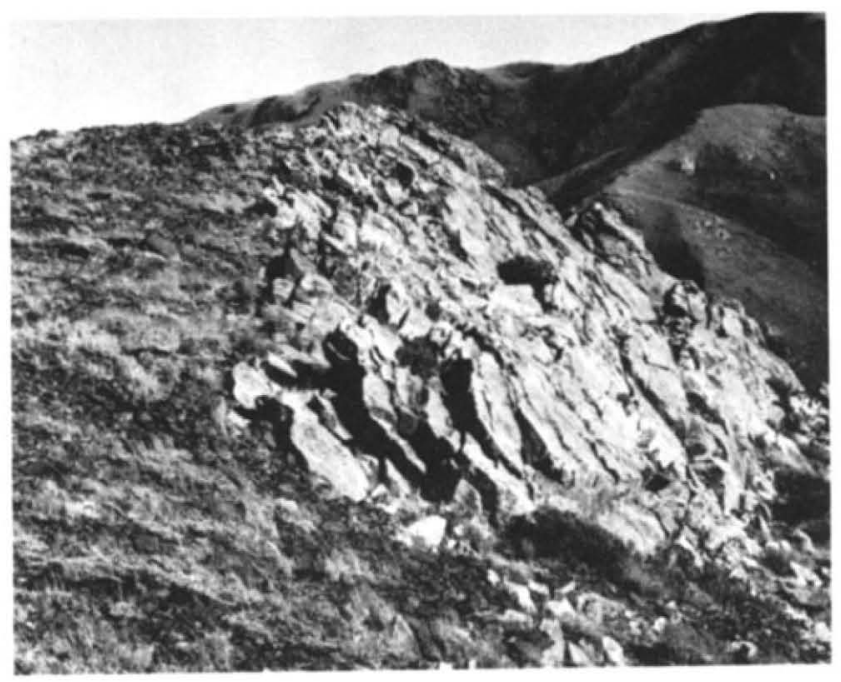

Figure 8. Lens of mature quartzite about 20 $m$ thick in sharp contact against graywacke and siltstone, graywacke member, Dutch Peak Formation, $2.3 \mathrm{~km}$ east of Dutch Peak.

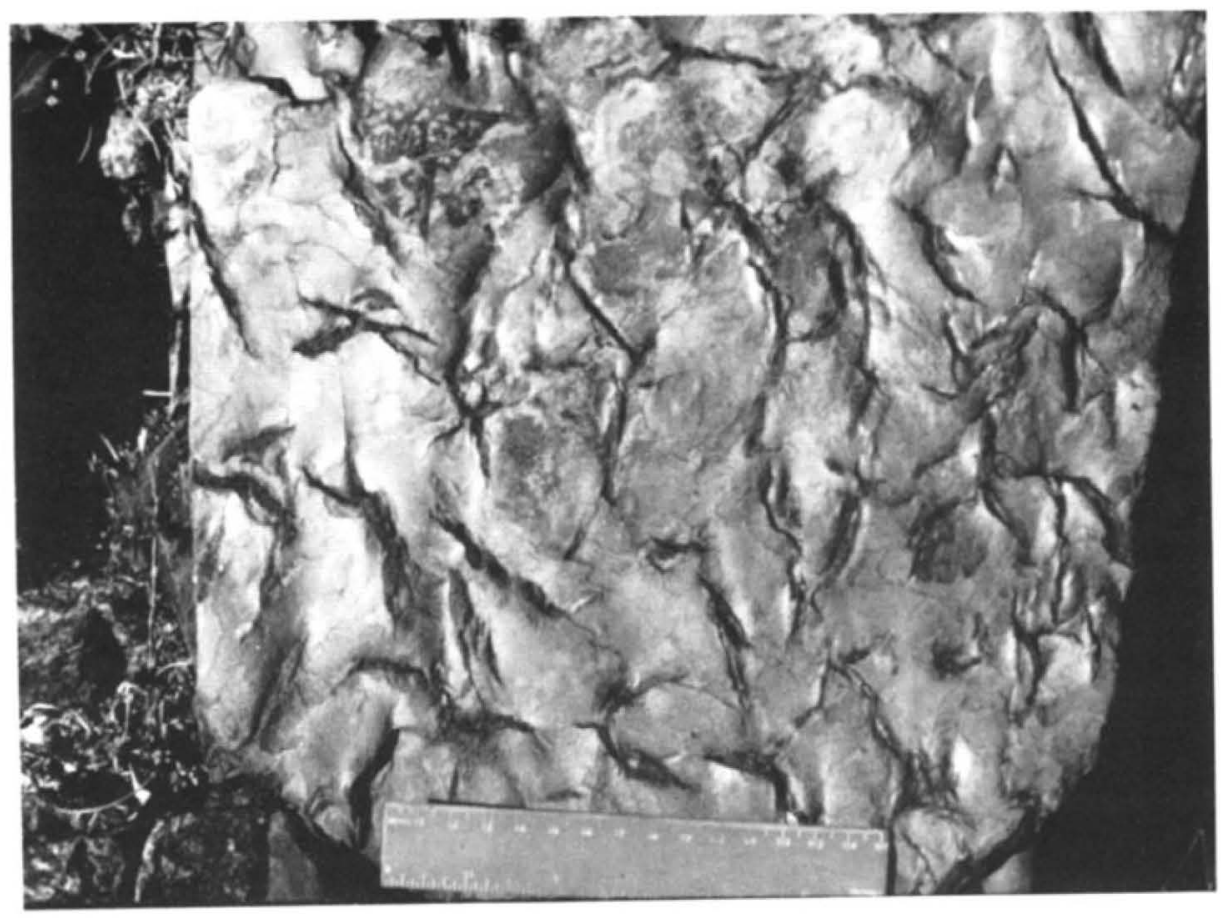

Figure 9. Bedding plane of micaceous siltstone with sandstone dikelets (syneresis structures), Caddy Canyon Formation, south side of Harker Canyon. Similar structures occur locally at top of Kelley Canyon Formation.

logic divisions within the Caddy Canyon Quartzite are typically lenticular, and the sequence encountered in one section may differ considerably from that traversed a few kilometres away (Blick, 1979).

In Utah and Idaho, quartzitic rocks underlying the Inkom Formation are regionally variable. One possible interpretation is that the Inkom overlies a disconformity and several quartzite units of different ages. However, the demonstration in the Sheeprock Mountains of pronounced lateral facies changes within the Caddy Canyon Quartzite and, except for one locality, transitional contact relations, suggests that important breaks are not present in this sequence.

Much of the outcrop here termed "Caddy Canyon Quartzite" in the northern Sheeprock and adjacent West Tintic Mountains was mapped tentatively by Cohenour (1959) and by Groff (1959) as Mutual Formation, presumably on the basis of a small proportion of liver-colored rocks reminiscent of the purplish hues of the Mutual. I similarly assigned the quartzite to the Mutual Formation, and locally underlying liver-colored argillite to the upper part of the Inkom Formation (Blick, 1977). Further work shows, however, that this correlation is incorrect for several reasons. (1) Livercolored rocks are subordinate and lenticular, and white quartzite is the dominant lithology. (2) The combination of pink and purple quartzite and grit of the miogeoclinal Mutual Formation is very distinctive, and on a regional scale it is lithologically invariable in comparison with the Caddy Canyon Quartzite. (3) To the south of Leamington Canyon, in the nearby Canyon Range (Fig. 1), the uppermost Caddy Canyon contains reddish siltstone interbeds, and rocks of this color are therefore not restricted to the Mutual Formation. Cohenour (1959) suggested an unconformity beneath the Mutual of the Sheeprock Mountains, because as mapped by him it rested on different rock types of the upper Sheeprock "Series." The need for such an unconformity disappears if much of the "Mutual" is really Caddy Canyon Quartzite.

Immediately south and east of Black Crook Peak (BCP in Fig. 2), the Kelley Canyon Formation is locally missing, and the Caddy Canyon and Inkom Formations are both thin. This is due not to nondeposition or erosion, but to low-angle normal faults.

\section{Inkom Formation}

The Inkom Formation consists of as much as $145 \mathrm{~m}$ of slate with subordinate sandstone and quartzite. The slate is generally olive-drab to green in the lower part but liver-colored with a greater proportion of quartzite in the upper part. South of Horse Valley, the Inkom is only $50 \mathrm{~m}$ thick. At this locality, several metres of conglomerate at the base are overlain by purple, olive-drab, and gray slate, shale, and siltstone. There are several lenses, as much as $15 \mathrm{~m}$ thick, of pink quartzite.

\section{Mutual Formation}

Overlying the Inkom Formation with sharp contact south of Horse Valley, and with transitional contact near Black Crook Peak (Fig. 2), there is as much as $500 \mathrm{~m}$ of grayish-red, pink, or purple feldspathic quartzite, grit, and conglomerate, which has been assigned to the Mutual Formation. In the upper part, there are several thin interbeds of blue-gray slate, and quartzite is 


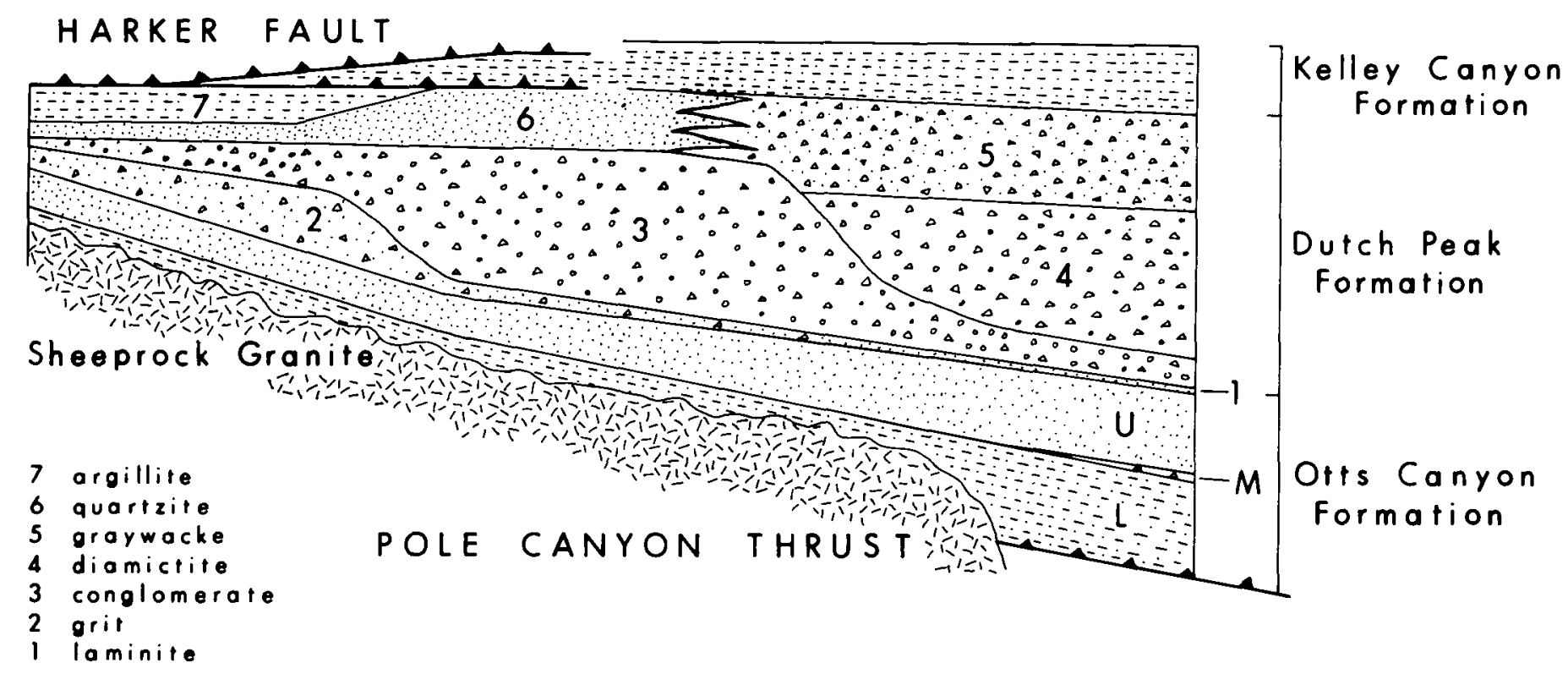

Informal members of

Dutch Poak Formation

Figure 10. Interpretation of lateral facies relations in the Sheeprock Group between Pole Canyon Thrust and Harker Fault. Some contacts are transitional. The nature of others is unclear.

pale green. The contact with the finergrained overlying Prospect Mountain Quartzite is transitional over as much as $100 \mathrm{~m}$. The contact is placed beneath quartzite that is predominantly fine to medium grained.

\section{Prospect Mountain Quartzite}

A well-exposed and complete stratigraphic section of the Prospect Mountain Quartzite crops out west of North Oak Brush Canyon (NOB in Fig. 2), where it is more than $1,000 \mathrm{~m}$ thick. The dominant lithology is white quartzite with thin pebble layers, particularly in the lower part.

Cohenour (1959) called this unit Tintic Quartzite, but Prospect Mountain is used in this paper following the practice of the U.S. Geological Survey to correlate Lower Cambrian Quartzite above the Tintic Valley Thrust (generally west of the Tintic Valley; $T$ in Fig. 1) with a section described by Nolan (1935) in the Gold Hill district of the Deep Creek Range (H. T. Morris, 27 November 1978, written commun.). The name "Prospect Mountain" was first used by Hague (1883) for exposures of quartzite in the Eureka district, Nevada.

The age of the unfossiliferous Prospect Mountain Quartzite is poorly constrained in the Sheeprock Mountains (Cohenour,
1959). The overlying Pioche Shale (50 to $105 \mathrm{~m}$ thick) contains fucoids and trilobite(?) tracks. Cohenour discovered the fauna of the Albertella zone (early Middle Cambrian) in limestone of the Tatow Formation (Busby Quartzite of Cohenour), 12 $\mathrm{m}$ above the contact with the Pioche. This suggests that most of the Prospect Mountain Quartzite is of Early Cambrian age, but the lower part may be Proterozoic.

\section{Lithologic Distinctions between Quartzites}

Quartzite layers of similar lithology occur in the Otts Canyon, Dutch Peak, Caddy Canyon, Mutual, and Prospect Mountain Formations. Where observable, stratigraphic position is definitive, but where quartzite occurs in isolated fault blocks, certain lithologic criteria summarized in Figure 11 are generally sufficient to distinguish quartzite of the various formations.

\section{Interpretation of Proterozoic Rocks}

A brief summary of the over-all interpretation of the rocks described follows. Detailed analysis of sedimentary facies will be the subject of a later publication.

A glacial origin for part of the Sheeprock Group was first proposed by Loughlin (in
Butler and others, 1920). Critical evidence consists of : (1) thick diamictite, (2) one striated clast, (3) dropstones and sand pellets in laminites and conglomerate clots in diamictite, and (4) the regional occurrence of similar rocks in a coherent stratigraphy (Fig. 3). Diamictite is well bedded and interfingers with better-sorted rock types such as quartzite and shale, suggesting marine sedimentation. The Sheeprock Group thus represents the influx of coarse glacial detritus into a subsiding basin in which mostly fine-grained sediment (shale) was deposited before and after glaciation.

The Brigham Group is interpreted as recording the progradation of shallowwater shelf sand into the basin (Caddy Canyon Quartzite), fluviatile sedimentation (Mutual Formation), followed by renewed shelf sedimentation during Cambrian time (Prospect Mountain Quartzite).

\section{REGIONAL CORRELATION}

Regional correlation of upper Proterozoic and Lower Cambrian rocks in northwestern Utah, southern Idaho, and eastern Nevada has been discussed by Misch and Hazzard (1962), Woodward (1963, 1965, 1967, 1968, 1972, 1976), Crittenden and others (1971), Stewart (1974), and Miller (1981). Detailed 
work in the Sheeprock Mountains, summarized in this paper, and brief visits to other localities suggest some modifications of earlier correlations.

The basis for proposed lithologic correlations is the identification in several ranges of sequences including certain distinctive rock types and associations. Two key elements are diamictite low in some sequences and the equally distinctive association near the top of these sequences of the Inkom and Mutual Formations, underlain by a variety of quartzitic rocks and overlain by Cam. brian quartzite known in different places as Camelback Mountain, Geertsen Canyon, Tintic, and Prospect Mountain. Lithologic correlation does not rule out a degree of diachroneity. However, the glacial interpretation of the diamictite (summarized by Blick, 1979; Ojakangas and Matsch, 1980; Christie-Blick, 1980; and Christie-Blick and others, 1980) suggests that these deposits are approximately synchronous. The age of the upper Proterozoic rocks is poorly known (Crittenden and others, 1971), but they are probably younger than about 950 $\mathrm{m} . \mathrm{y}$. and perhaps as young as $650 \mathrm{~m} . \mathrm{y}$. ( $\mathrm{K}$ noll and others, 1981). Many contacts in the miogeoclinal sequences are transitional, and there is little direct evidence for unconformities. However, the older the diamictite, the more likely is the presence of undetected paraconformities.

Unfortunately, diamictite does not crop out in Nevada or south of a line between the Sheeprock Mountains and Deep Creek Range in Utah (Fig. 1). The Inkom and Mutual Formations extend westward with certainty only to the Dugway Range, and correlations between the post-diamictite Huntsville sequence and the McCoy Creek Group of Nevada and western Utah (Misch and Hazzard, 1962) are tenuous. South of the Sheeprock Mountains, facies and thickness changes and a lack of distinctive rock types hamper correlation of pre-Inkom beds in the San Francisco Mountains (Beaver Mountains of Woodward, 1968) and Canyon Range.

\section{San Francisco Mountains and Canyon Range}

In the San Francisco Mountains and Canyon Range, Crittenden and others (1971) and Woodward $(1972,1976)$ tentatively assigned strata to the upper Pocatello Formation, Blackrock Canyon Limestone,

\begin{tabular}{|c|c|c|}
\hline FORMATION & Otis Canyon & Durch Peak \\
\hline MEMBER & upper & quartzite \\
\hline $\begin{array}{l}\text { FRESH } \\
\text { WEATHERED }\end{array}$ & $\begin{array}{l}\text { gray } \\
\tan \end{array}$ & $\begin{array}{c}\text { light oray, white } \\
\text { ton, brown }\end{array}$ \\
\hline GRAIN SIZE & fine to medium & fine to medium \\
\hline SORTING & moderately good & good \\
\hline FELDSPAR CONTENT & variable & low \\
\hline INTERBEDS & col or gw ss sl sli sh & sl \\
\hline$\%$ OF SECTION & $<10 \%$ & very rare \\
\hline $\begin{array}{c}\text { SEDIMENTARY STRUCTURES } \\
\text { COMMON }\end{array}$ & $\begin{array}{l}\text { even parallel } \\
\text { laminations }\end{array}$ & $\begin{array}{l}\text { Oven porallel } \\
\text { laminations }\end{array}$ \\
\hline LESS COMMON & cross - bedding & \\
\hline DISTINCTIVE FEATURES & $\begin{array}{l}\text { lithic fragments } \\
\text { diabose sills }\end{array}$ & $\begin{array}{l}\text { low interbeds } \\
\text { no cross-bedding }\end{array}$ \\
\hline
\end{tabular}

Figure 11. Lithologic distinctions between Proterozoic and Cambrian quartzite units in Sheeprock Mountains. Lithologic abbreviations: cgl, conglomerate; gr, grit; gw, graywacke; ss, sandstone; sl, slate; slt, siltstone; sh, shale.

Papoose Creek Formation, and Caddy Canyon Quartzite, all of which they correlated from southeastern Idaho (Fig. 12). However, the pre-Inkom sections are sufficiently different from the standard sequence that new nomenclature is probably required and such detailed correlation is unwarranted.

Shale of the upper Pocatello Formation and stratigraphically equivalent Kelley Canyon Formation constitutes a persistent unit not only in southeastern Idaho and northern Utah, including the Sheeprock Mountains (Fig. 3), but throughout the Cordillera (Christie-Blick and others, 1980). The oldest rocks exposed in the San Francisco Mountains and Canyon Range are primarily quartzite and quite unlike the upper Pocatello Formation.

The Blackrock Canyon Limestone (Fig. 3) perhaps extends southward as far as Huntsville (Fig. 1), where carbonate beds occur in the Kelley Canyon Formation, but not to the Sheeprock Mountains. The absence of this carbonate unit in the Sheeprocks could be due to a relatively basinward palinspastic position, and it is possible that Blackrock Canyon equivalents occur in the San Francisco Mountains and Canyon Range. On the other hand, carbonate rocks are a minor constituent at several horizons in the upper Proterozoic sequence at many localities.
Typical Papoose Creek Formation (Fig. 3), characterized by crumpled syneresis structures in thinly interbedded siltstone and quartzite, does not occur above the carbonate beds in either the San Francisco Mountains or Canyon Range, although it is locally developed in the Sheeprock Mountains.

Rocks considered by Crittenden and others (1971) and Woodward $(1972,1976)$ to be Caddy Canyon Quartzite are only $410 \mathrm{~m}$ thick in the Canyon Range (unit 9 of Christiansen, 1952) and $80 \mathrm{~m}$ thick in the San Francisco Mountains (unit 3 of Woodward, 1968), whereas this unit is at least $2,000 \mathrm{~m}$ thick in the Sheeprock Mountains. In comparison, thicknesses of the Inkom and $\mathrm{Mu}$ tual Formations and the Prospect Mountain (or Tintic) Quartzite in the three ranges are comparable (Table 1 and Fig. 13), suggesting approximately equivalent subsidence rates. It is possible that subsidence history could have been markedly different during and before Caddy Canyon time, as suggested by the relatively thin Caddy Canyon Quartzite at Huntsville (Figs. 1 and 3). However, the disparity in thicknesses, the fact that the Caddy Canyon Quartzite is lithologically heterogeneous even within the Sheeprock Mountains (Blick, 1979), and the difficulty of identifying pre-Caddy Canyon units south of the Sheeprocks suggest that units 1-9 in the Canyon Range and units 


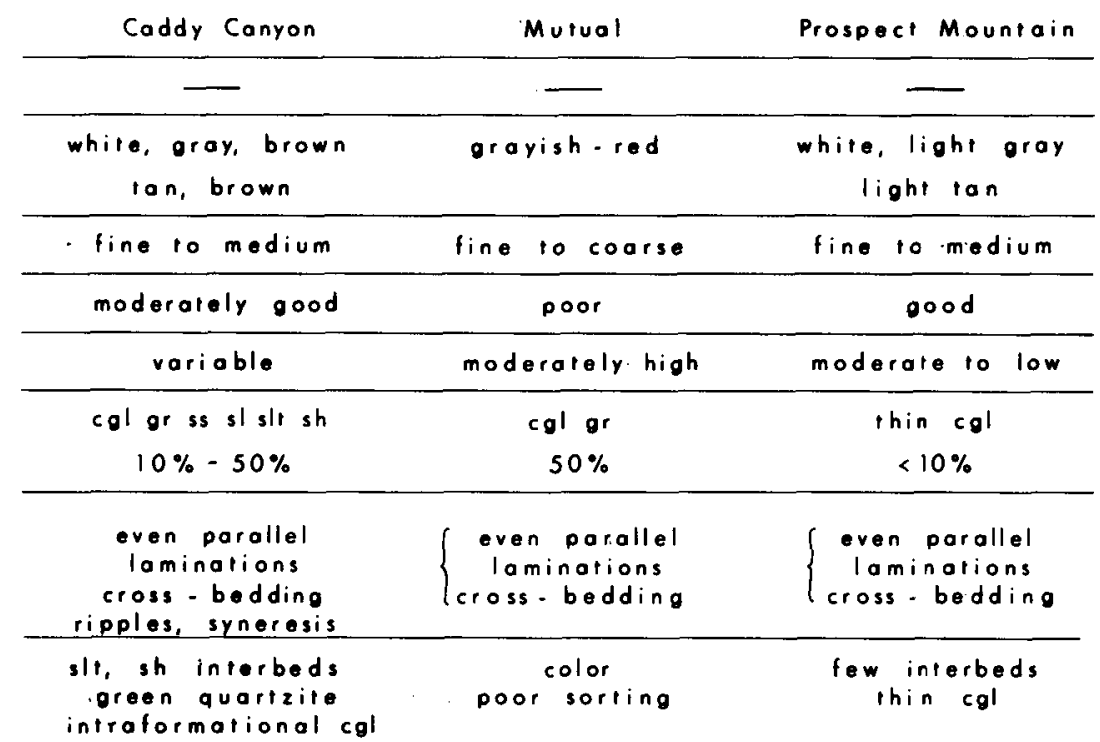

Figure 11. (Continued).
$1-3$ in the San Francisco Mountains (Fig. 12) may all be equivalent to the Caddy Canyon Quartzite, even if this name is not applied to them.

\section{Western Utah and Adjacent Nevada and Southwestern Idaho}

Diamictite crops out in the southern part of the Deep Creek Range (Fig. 1), in units 3 and 5 of the "Trout Creek sequence" (Fig. 14) of Misch and Hazzard (1962). Several bedding-plane faults occur in the section, and it is not certain how dolomitic marble and mica schist of units 1 and 2 are related to the rest of the sequence (Bick, 1966). The rocks are in the garnet and staurolite grades of regional metamorphism (Nelson, 1969) and have a complex metamorphic and deformational history. Their schistose fabric makes it difficult to interpret relict sedimen-

tary structures or even to determine facing directions.

Bick (1966) renamed the rocks "Horse Canyon Formation" because "Trout Creek" is in prior stratigraphic use, although Nelson $(1966,1969)$ continued to use the nomenclature of Misch and Hazzard (1962). Bick divided the Horse Canyon into four informal members (Fig. 14), and suggested that there is only one diamictite unit (his member b) repeated by a tight syncline, which is cored by quartzite of his member a (unit 4 of Misch and Hazzard, 1962). Possible cross-bedding in the lower part of unit 3 suggests that beds face westward (upright), but a scour-and-fill structure(?) near the contact with unit 4 suggests that the beds are overturned, as claimed by Bick (1966). Neither geopetal indicator is very convincing, and it is possible that there is considerable mesoscopic folding within the units.

TABLE I. THICKNESSES OF STRATIGRAPHIC UNITS

\begin{tabular}{lccc}
\hline & $\begin{array}{c}\text { San Francisco } \\
\text { Mountains (m) }\end{array}$ & $\begin{array}{c}\text { Canyon Range } \\
(\mathrm{m})\end{array}$ & $\begin{array}{c}\text { Sheeprock } \\
\text { Mountains (m) }\end{array}$ \\
\hline Prospect Mountain or Tintic Quartzite & $1,220-2,135$ & $455-1,050$ & $785-1,350$ \\
Mutual Formation? & 635 & $510^{+}$ & $430-510$ \\
Inkom Formation & 160 & 165 & $30-145$ \\
Caddy Canyon Quartzite and equivalents* & $770^{+}$ & $1,150^{+}$ & $2,000^{+}$ \\
\hline
\end{tabular}

Note: these measurements assume correlations proposed in this paper.

*Thickness of exposed sub-Inkom section for San Francisco Mountains and Canyon Range.
Bedding-cleavage relations are not very helpful in detecting facing reversals because the surfaces are nearly everywhere close to parallel where.I examined them in Trout Creek. The structural and geopetal data available are insufficient to support Bick's (1966) contention that there is only one diamictite unit repeated by a fold. In addition, there appear to be.important lithologic differences between units 3 and 5 . The dominant lithology of.unit 3 is sparsely pebbly schist, apparently less sandy and gritty, and better bedded than the generally more crowded pebbly diamictite of unit 5 . While it is possible that these differences could be due to a lateral facies change, I believe the weight of evidence favors the.interpretation of Misch and.Hazzard (1962) that there are two diamictite units. The diamictites and intervening quartzite may be laterally equivalent to similar units in the Otts Canyon and Dutch Peak Formations of the Sheeprock Mountains (Fig. 15).

The upper part of the section is considerably less metamorphosed in the northern Deep Creek Range. Bick $(1959,1966)$ described a sequence of quartzite and shale, which he termed "Goshute Canyon Formation," overlain by the Prospect Mountain Quartzite restricted from Nolan's (1935) usage. Woodward (1965) suggested correlations between the same rocks and the McCoy Greek Group of Misch and Hazzard (1962) in eastern Nevada (Fig. 15).

In the southern Snake Range and Schell Creek Range, brownish-weathering Prospect Mountain Quartzite overlies the white to light gray Stella Lake Quartzite with sharp, possible paraconformable contact (Misch and Hazzard, 1962). The Stella Lake Quartzite (or unit $\mathrm{H}$ of the McCoy Creek Group) is thin or absent in the Egan Range and absent in the Pilot and Deep Creek Ranges (Woodward, 1967). Either the Stella Lake is a laterally restricted facies or it is overlain by a regionally significant disconformity. The former interpretation is favored.here because of the transitional lower contact of the Prospect Mountain Quartzite in the Drum and Sheeprock Mountains and of the Tintic Quartzite in the Canyon Range, all these localities lying east of the Deep Creek and Pilot Ranges. Miller (1981) has come to the same conclusion from studying rocks in the Pilot and Albion Ranges (Fig. 1).

Contrary to Bick (1966), the Goshute Canyon Formation of the Deep Creek 


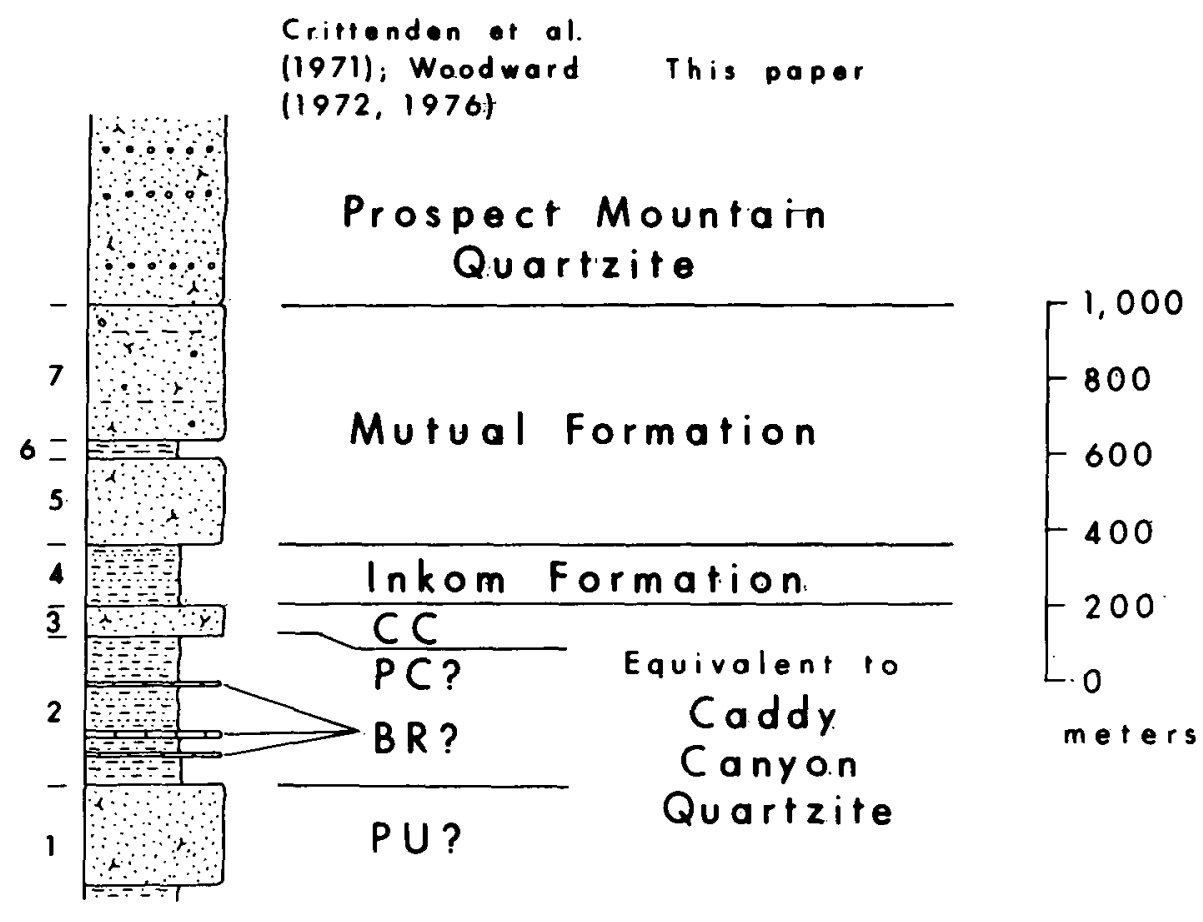

San Francisco Mountains

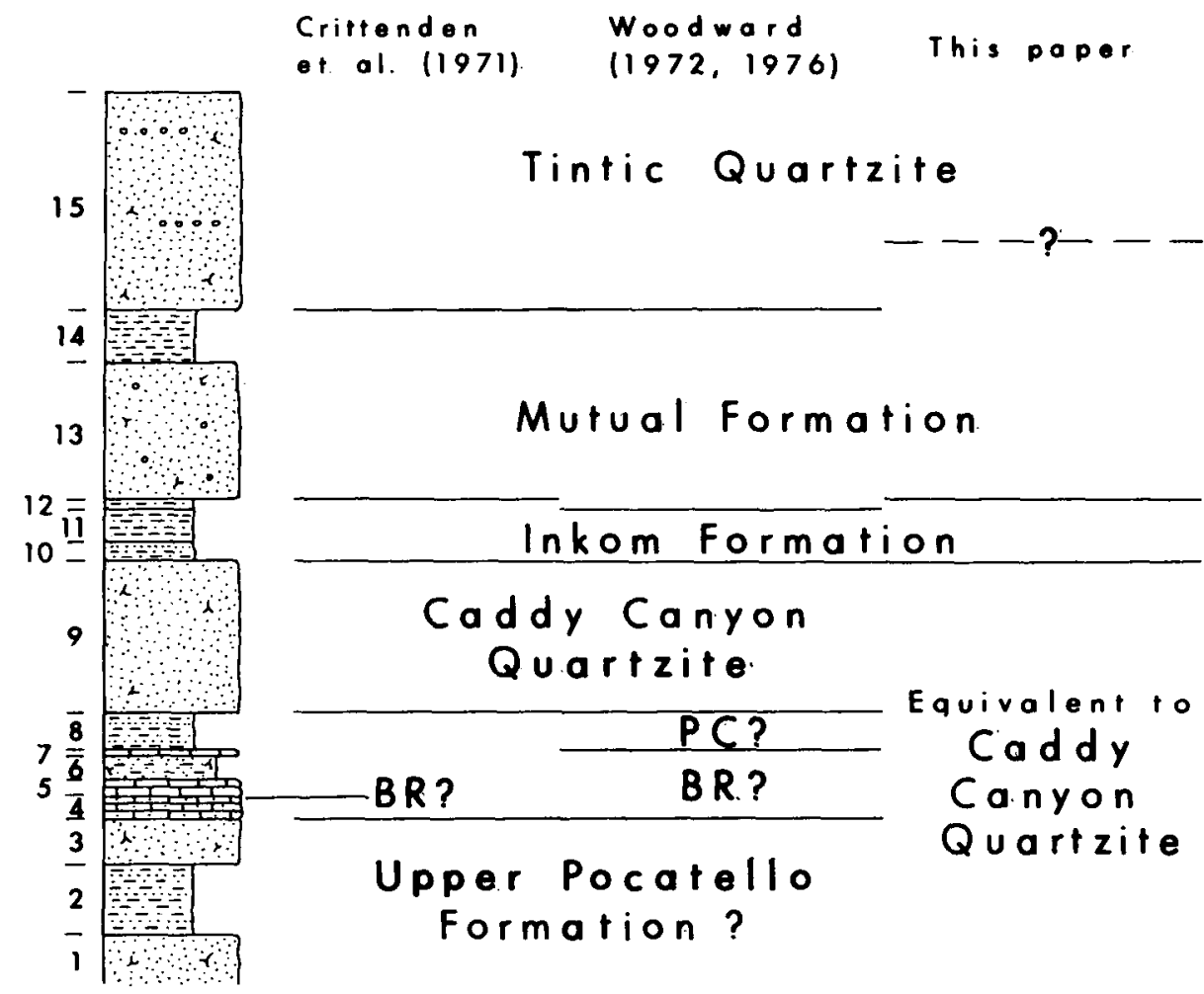

\section{Canyon Range}

Figure 12. Upper Proterozoic and Lower Cambrian stratigraphy of San Francisco Mountains (A) and Canyon Range (B), indicating published correlations and those proposed in this paper. Sources of data: Woodward, 1968; Christiansen, 1952. Abbreviations for stratigraphic units as in Figure 3.
Range does not resemble the Mutual Formation of the Sheeprock Mountains (Blick, 1979). The uppermost $30-40 \mathrm{~m}$ of his member d (unit G of Woodward, 1965), olive-drab siltstone overlain by bluish-gray slaty siltstone, may be equivalent to the Inkom Formation. Beds in the lowest 50$100 \mathrm{~m}$ of the Prospect Mountain Quartzite, pink or purple grit and layers of pebble conglomerate, resemble the Mutual Formation but are very thin.

Several correlations are possible between the upper part of the McCoy Creek Group and the Huntsville sequence. Two are discussed here. In the first (favored by Woodward, 1968), the Mutual Formation is laterally equivalent to units $F$ and $G$ of the McCoy Creek Group (see Fig. 15). Purple feldspathic grit is present although subordinate in unit. F (mostly gray or white quartzite and conglomerate), but the Inkom Formation is a poor match for the more quartzitic unit $\mathrm{E}$. In the second interpretation (tentatively favored here), the $\mathrm{Mu}$ tual Formation is perhaps represented by tongues of grit in unit $\mathbf{H}$ (Stella Lake Quartzite), here included within the Prospect Mountain Quartzite, following Whitebread (1969) and Hose and Blake (1970). The Inkom Formation is then approximately equivalent to unit $\mathrm{G}$ (the Osceola Argillite). The Caddy Canyon Quartzite is equivalent to unit $F$ and the underlying sequence of interbedded quartzite, shale, siltstone, and phyllite. The last correlation implies that regionally. the Caddy Canyon Quartzite intertongues with finer-grained strata toward the west as well as toward the south.

\section{Possible Late Proterozoic Transgression}

The Osceola Argillite is a distinctive unit consisting of gray and. bluish-gray siltstone and shale, finely laminated with very fineto fine-grained gray quartzite. Sedimentary structures are micro-cross-laminations, graded bedding, starved ripples, and flaser bedding. The last of these resembles structures locally developed in the upper part of the Inkom Formation of the Sheeprock Mountains. Stewart (1974) reported limestone and silty limestone in the Osceola Argillite in the Wheeler Peak area of the Snake Range. Woodward (1967) and Miller (1981) described similar rocks in apparently equivalent units of the Pilot and Albion Ranges. Stewart (1974) emphasized the lithologic similarity between the Osceola Argillite and the Rainstorm Member of the Johnnie Formation of southeastern Cali- 


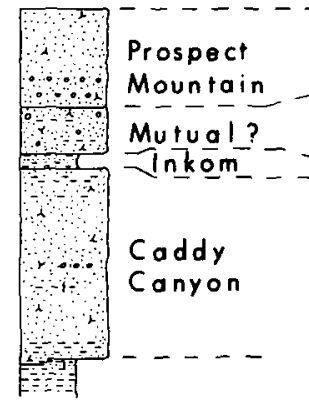

Sheoprock Mountains

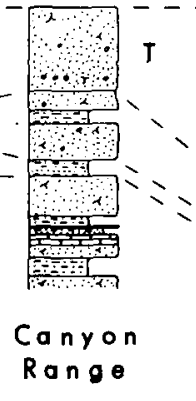

Dugway
Range
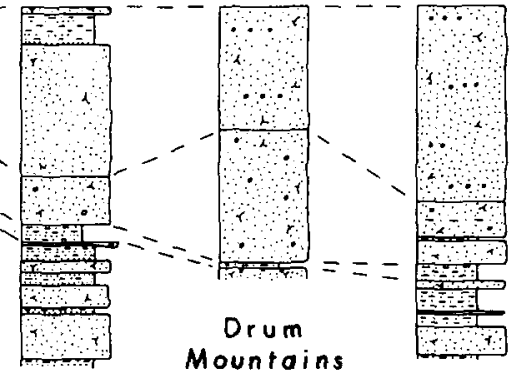

San

Francisco

Mountains

Figure 13. Upper Proterozoic and Lower Cambrian stratigraphy in west-central Utah, with suggested correlations. Sources of data: Sheeprock Mountains (this paper); Canyon Range (Christiansen, 1952); Dugway Range (Staatz and Carr, 1964); Drum Mountains -(Blick, 1979; Dommer, 1980); San Francisco Mountains (Woodward, 1968).

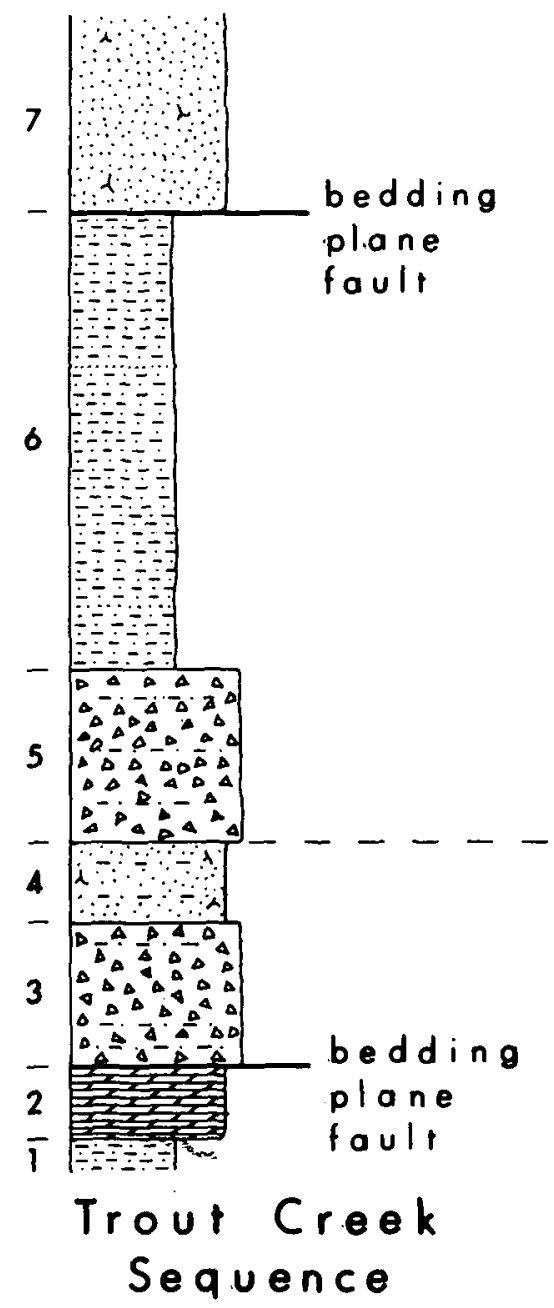

Misch \& Hazzard (1962)

\section{Horse Canyon Formation}

\footnotetext{
or Metadiamictite

$\therefore$ ari: Quartzite
}

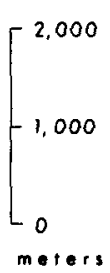

meters

$$
\text { in }
$$
stratigraphic position, is the important fact that in each of the three outcrop areas, the units are persistent and relatively invariable in comparison with underlying rocks, which are characterized by pronounced lateral facies changes. A possible explanation for a widespread fine-grained unit is a marine transgression, initiated by an increase in the rate of eustatic sea-level rise (or a decrease in the rate of fall) (Pitman, 1978), over a surface with little relief. Benmore (1978) and Benmore and Boles (.1980) have demonstrated remarkable petrographic similarities between a thin, laterally persistent oolite bed in the Rainstorm Member of the Johnnie and Holocene transgressive ooid sediments on the Bahama Banks and that the oolite represents a major transgression at least in the Californian sector of the miogeocline.

\section{Regional Correlation of the Mutual Formation}

Since first coined by Crittenden and others (1952) for grayish-red quartzite and grit in the vicinity of Big Cottonwood Canyon in the Wasatch Range (Fig. 1), the term "Mutual" has had an unsettled history. Lithologically similar rocks in the Uinta Mountains were early thought to be correlative with the Mutual Formation. However, a provisional $\mathrm{Rb}-\mathrm{Sr}$ age of $952 \pm 5 \mathrm{~m}$.y. for the top of the Uinta Mountain Group (Crittenden and Peterman, 1975) and recent work by Chaudhuri and Hansen (1980) suggest the match to be unlikely. Larsen (1957) correlated dolomite, slate, and quartzite overlying the glaciogenic Mineral Fork Formation of Antelope Island with the Mutual Formation. However, the dolomite and slate are lithologically similar to the Kelley Canyon Formation, and the quartzite is definitely Tintic (Crittenden and others, 1971). Cohenour (1959) suggested that strata between his Sheeprock "Series" and the Prospect Mountain (his Tintic) Quartzite were equivalent to the Mutual Formation, although the lower part is now

Figure 14. Stratigraphy of upper Proterozoic rocks in Trout Creek, eastern Deep Creek Range (from Misch and Hazzard, 1962; Bick, 1966). 


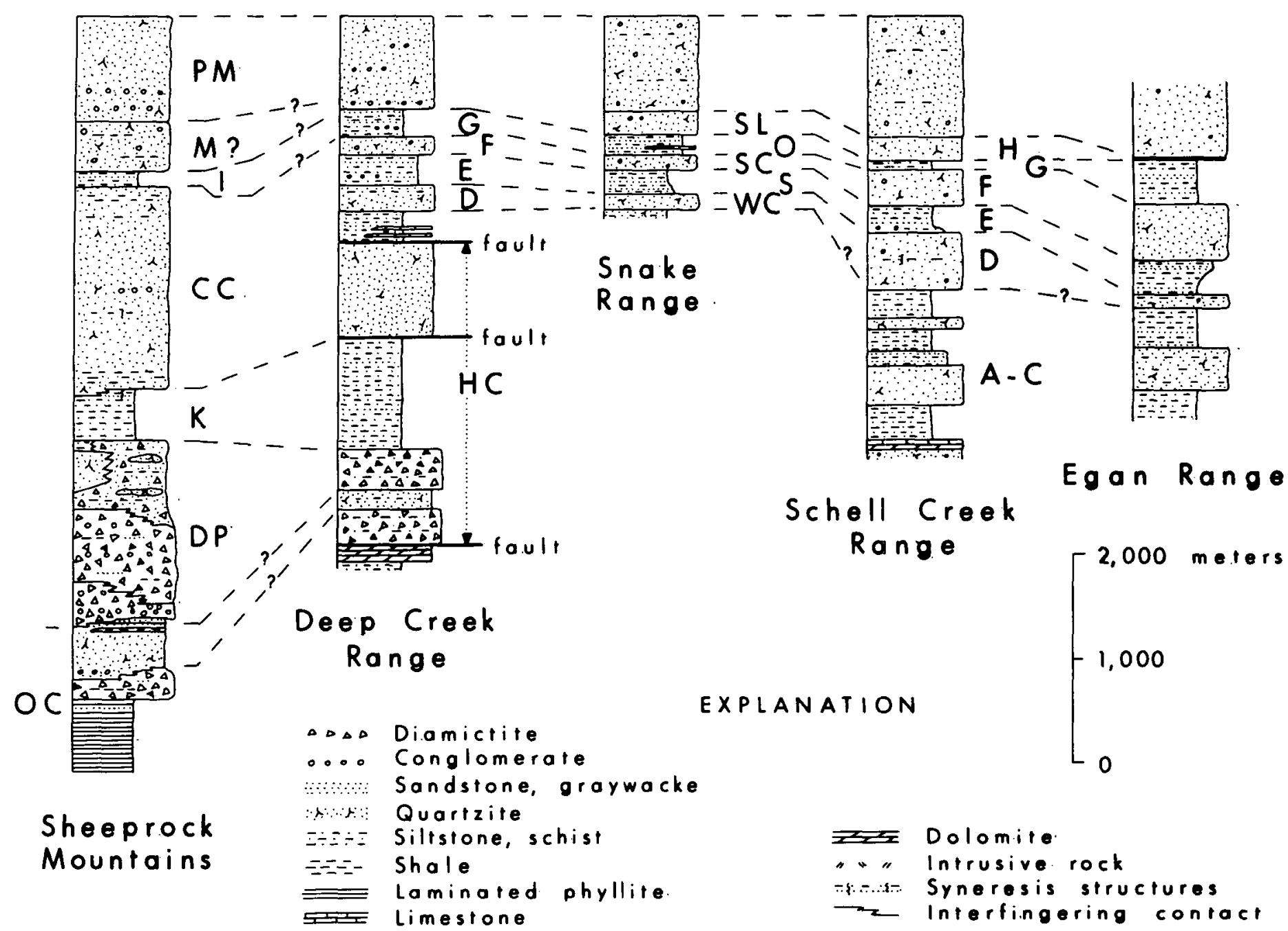

Figure 15. Upper Proterozoic and Lower Cambrian stratigraphy in western Utah and eastern Nevada, with preferred correlations. Sources of data: Sheeprock Mountains (this paper); Deep Creek Range (Misch and Hazzard, 1962; Bick, 1959, 1966; Woodward, 1965); Snake Range (Misch and Hazzard, 1962; Whitebread, 1969); Schell Creek Range (Misch and Hazzard, 1962; Hose and Blake, 1970; Young, 1960; Stewart, 1974); Egan Range (Woodward, 1963). Stratigraphic units: PM, Prospect Mountain Quartzite; M, Mutual Formation; I, Inkom Formation; CC, Caddy Canyon Quartzite; K, Kelley Canyon Formation; DP, Dutch Peak Formation; OC, Otts Canyon Formation; A-H, informal subdivisions of McCoy Creek Group; HC, Horse Canyon Formation; SL, Stella Lake Quartzite; O, Osceola Argillite; SC, Shingle Creek Quartzite; S, Strawberry Creek Formation; WC, Willard Creek Quartzite.

considered by me to be Inkom Formation, and many of his Mutual outcrops are Caddy Canyon Quartzite (this paper). Rocks originally identified as correlatives of the middle Proterozoic Big Cottonwood Formation (see Muessig, 1951; Morris and Lovering, 1961; Demars, 1956; Smith, 1956) were assigned by Woodward $(1972,1976)$ to the Mutual. However, were it not for the color contrast and intervening Mineral Fork Formation, even in the type area the Mutual would be indistinguishable from the Big Cottonwood Formation (Crittenden and others, 1952).

In allochthonous parts of the Sevier orogenic belt (Armstrong, 1968b), the Mutual Formation is lithologically distinctive, re- gionally invariable, and generally easily identifiable, especially where bounding formations are present. However, there is some doubt about the validity of the correlation from the autochthonous type area to the miogeocline, which Crittenden and others (1971) proposed on the basis of lithology, color, and stratigraphic position (Fig. 3) Stratigraphic position is not particularly helpful and requires only that the miogeoclinal Mutual equivalent lie somewhere between the top of the Dutch Peak Formation (and lateral equivalents, Fig. 3) and the base of the Prospect Mountain Quartzite and equivalent strata. Lithologically, the miogeoclinal Mutual resembles the type Mutual of the platform sequence in Big
Cottonwood Canyon and American Fork Canyon (B and A in Fig. 1), but, as discussed above, lithologic similarity has already led to several incorrect correlations. It is possible, therefore, although. not yet demonstrable, that rocks termed Mutual in the miogeocline are not equivalent to the type Mutual Formation, which may instead be an eastern facies of the Caddy Canyon Quartzite, for example. Paleomagnetism may offer a possible test, especially because there is evidence for rapid apparent polar wander in late Proterozoic time (Van Alstine and Gillett, 1979). In the interim, correlation of the platform and miogeoclinal Mutual remains the simplest interpretation, but only a tentative one. 


\section{CONCLUSIONS}

Specific upper Proterozoic formations, defined in northern Utah and southeastern Idaho, have been recognized and mapped in the Sheeprock Mountains. Diamictite of glacial origin occurs in two units separated by several hundred metres of quartzite in the Otts Canyon and Dutch Peak Formations. Overlying siltstone and quartzite are correlated with the Kelley Canyon, Caddy Canyon, Inkom, Mutual, and Prospect Mountain Formations (the last for the most part of Cambrian age). The term "Sheeprock" is raised to group status.

Upper Proterozoic rocks of the San Francisco Mountains and Canyon Range are possibly no older than the Caddy Canyon Quartzite, although previously suggested to include rocks correlative with the upper Pocatello Formation of Idaho. In the proposed interpretation, the Caddy Canyon Quartzite interfingers with siltstone, shale, and carbonate toward the south.

The probable presence of two diamictite divisions in the Deep Creek Range is reaffirmed. The overlying McCoy Creek Group for the most part is equivalent to the Caddy Canyon Quartzite, which interfingers with siltstone and shale toward the west. Unit $G$ of the McCoy Creek Group (the Osceola Argillite), previously correlated by Stewart (1974) with the Rainstorm Member of the Johnnie Formation in southeastern California, may be in part equivalent to the Inkom Formation. The wide distribution of these pelitic rocks suggests a possible late Proterozoic transgression, initiated by an increase in the rate of eustatic sea-level rise (or a decrease in the rate of fall), over a surface with little relief.

The Mutual Formation of the thick miogeoclinal sequences may not be a timeequivalent of the type Mutual of the thin platform sequence in the Wasatch Range. A paleomagnetic test is suggested.

\section{ACKNOWLEDGMENTS}

I thank many geologists for long discussions about regional stratigraphy and correlation, particularly M. D. Crittenden, Jr., H. T. Morris, and D. M. Miller, although none of these necessarily agrees with the interpretations suggested in this paper. The manuscript was improved by reviews by $\mathbf{M}$. D. Crittenden, Jr., J. C. Crowell, L. F. Hintze, P. K. Link, H. T. Morris, and L. A. Woodward. The research was supported by National Science Foundation Grants ATM
74-24201, EAR 77-06008, and EAR 7815194 to J. C. Crowell as part of a regional study of alleged glacial deposits of Proterozoic age in northwestern Utah. Publication has been approved by Exxon Production Research Company.

\section{REFERENCES CITED}

Armstrong, R. L., 1968a, The Cordilleran miogeosyncline in Nevada and Utah: Utah Geological and Mineralogical Survey Bulletin $78,58 \mathrm{p}$.

- 1968b, Sevier orogenic belt in Nevada and Utah: Geological Society of America Bulletin, v. 79, p. 429-458.

— 1970, Geochronology of Tertiary igneous rocks, eastern Basin and Range Province, western Utah, eastern Nevada, and vicinity, U.S.A.: Geochimica et Cosmochimica Acta, v. 34, p. 203-232.

Benmore, W. C., 1978, Stratigraphy, sedimentology, and paleoecology of the late Paleophytic or earliest Phanerozoic Johnnie Formation, eastern California and southwestern Nevada [Ph.D. dissert.]: Santa Barbara, University of California, $243 \mathrm{p}$.

Benmore, W. C., and Boles, J. R., 1980, Comparison of Holocene cements from Joulters Cay, Bahamas with Precambrian cements from the Johnnie Formation, eastern California and Nevada [abs.]: Geological Society of America Abstracts with Programs, v. 12, no. 7, p. 385 .

Bick, K. F., 1959, Stratigraphy of Deep Creek Mountains, Utah: American Association of Petroleum Geologists Bulletin, v. 43, p. 1064-1069.

- 1966, Geology of the Deep Creek Mountains, Tooele and Juab Counties, Utah: Utah Geological and Mineralogical Survey Bulletin 77, $120 \mathrm{p}$.

Blick, N., 1976, Late Proterozoic glaciation: Evidence in Sheeprock Mountains, Utah [abs.]: Geological Society of America Abstracts with Programs, v. 8, no. 6, p. 783-784.

__ 1977, Diachronous upper Proterozoic glacial deposits, Idaho and Utah [abs.]: Geological Society of America Abstracts with Programs, v. 9 , no. 7 , p. 901 .

Blick, N. H., 1979, Stratigraphic, structural and paleogeographic interpretation of upper Proterozoic glaciogenic rocks in the Sevier orogenic belt, northwestern Utah [Ph.D. dissert.]: Santa Barbara, University of California, $633 \mathrm{p}$.

Butler, B. S., Loughlin, G. F., Heikes, V. C., and others, 1920, The ore deposits of Utah: U.S. Geological Survey Professional Paper 111, $672 \mathrm{p}$.

Chaudhuri, S., and Hansen, W. R., 1980, Rb-Sr ages of the Uinta Mountain Group of Utah and Colorado [abs.]: Geological Society of America Abstracts with Programs, v. 12, no. 6 , p. 269

Christiansen, F. W., 1952, Structure and stratigraphy of the Canyon Range, central Utah: Geological Society of America Bulletin, v. 63 , p. $717-740$.

Christie-Blick, N., 1980, Glacial advance and retreat sequences, upper Proterozoic Min- eral Fork Formation, northwestern Utah [abs.]: Geological Society of America Abstracts with Programs, v. 12, no. 6, p. 269.

Christie-Blick, N., Link, P. K., Miller, J.M.G., Young, G. M., and Crowell, J. C., 1980, Regional geologic events inferred from upper Proterozoic rocks of the North American Cordillera [abs.]: Geological Society of America Abstracts with Programs, v. 12, no. 7, p. 402.

Cohenour, R. E., 1959, Sheeprock Mountains, Tooele and Juab Counties: Precambrian and Paleozoic stratigraphy, igneous rocks, structure, geomorphology, and economic geology: Utah Geological and Mineralogical Survey Bulletin 63, $201 \mathrm{p}$.

- 1970, Sheeprock Granite, in Whelan, J. A., compiler, Radioactive and isotopic age determinations of Utah rocks: Utah Geological and Mineralogical Survey Bulletin 8I, p. 31 .

Crittenden, M. D., Jr., and Peterman, Z. E., 1975, Provisional Rb/Sr age of the Precambrian Uinta Mountain Group, northeastern Utah: Utah Geology, v. 2, no. 1, p. 75-77.

Crittenden, M. D., Jr., and Wallace, C. A., 1973 Possible equivalents of the Belt Supergroup in Utah, in Belt Symposium, Volume 1: Moscow, Idaho, University of Idaho, p. 116-138.

Crittenden, M. D., Sharp, B. J., and Calkins, F. C., 1952, Geology of the Wasatch Mountains east of Salt Lake City, Parleys Canyon to Traverse Range, in Marsell, R. E., ed., Geology of the central Wasatch Mountains: Utah Geological and Mineralogical Survey, Guidebook to the Geology of Utah, no. 8, p. 1-37.

Crittenden, M. D., Jr., Schaeffer, F. E., Trimble, D. E., and Woodward, L. A., 1971, Nomenclature and correlation of some upper Precambrian and basal Cambrian sequences in western Utah and southeastern Idaho: Geological Society of America Bulletin, v. 82, p. 581-602.

Demars, L. C., 1956, Geology of the northern part of Dry Mountain, southern Wasatch Mountains, Utah: Brigham Young University Research Series, v. 3, no. 2, 49 p.

Dommer, M. L., 1980, Geology of the Drum Mountains, Millard and Juab Counties, Utah [abs.]: Geological Society of America Abstracts with Programs, v. 12, no. 6, p. 272.

Eardley, A. J., and Hatch, R. A., 1940, Proterozoic(?) rocks in Utah: Geological Society of America Bulletin, v. 51, p. 795-843.

Gardner, W. C., 1954, Geology of the West Tintic Mining District and vicinity, Juab County, Utah [M.S. thesis]: Salt Lake City, University of Utah, $43 \mathrm{p}$.

Groff, S. L. 1959, Geology of the West Tintic Range and vicinity, Tooele and Juab Counties, Utah [Ph.D. thesis]: Salt Lake City, University of Utah, $183 \mathrm{p}$.

Hague, A., 1883, Abstract of the report on the geology of the Eureka district, Nevada: U.S. Geological Survey, third annual report, p. 237-290.

Harris, D., 1958, The geology of Dutch Peak area, Sheeprock Range, Tooele County, Utah: Brigham Young University Research Studies, Geology series, v. 5, no. 1, 82 p.

Hose, R. K., and Blake, M. C., Jr., 1970, Geologic map of White Pine County, Nevada: U.S. Geological Survey Open-File Map. 
Knoll, A. H., Blick, N., and Awramik, S. M., 1981, Stratigraphic and ecologic implications of late Precambrian microfossils from Utah: American Journal of Science, v. 281, p. 247-263.

Larsen, W. N., 1957, Petrology and structure of Antelope Island, Davis County, Utah [Ph.D. thesis]: Salt Lake City, University of Utah, $142 \mathrm{p}$.

Link, P. K., Bright, R. C., and Trimble, D. E., 1980 , New discoveries in the upper Proterozoic stratigraphy of southeastern Idaho [abs.]: Geological Society of America Abstracts with Programs, v. 12, no. 6, p. 278.

Miller, D. M., 1981, Proposed correlation of an allochthonous quartzite sequence in the Albion Mountains, Idaho with Proterozoic $\mathrm{Z}$ and Lower Cambrian strata of the Pilot Range, Utah and Nevada: U.S. Geological Survey Open-File Report 81-463, 26 p.

Misch, P., and Hazzard, J. C. 1962, Stratigraphy and metamorphism of late Precambrian rocks in central northeastern Nevada and adjacent Utah: American Association of Petroleum Geologists Bulletin, v. 46, p. 289-343.

Morris, H. T., and Kopf, R. W., 1967, Breccia pipes in the West Tintic and Sheeprock Mountains, Utah: U.S. Geological Survey Professional Paper 575-C, p. 66-71.

_ 1970a, Preliminary geologic map and cross section of the Cherry Creek Quadrangle and adjacent part of the Dutch Peak Quadrangle, Juab County, Utah: U.S. Geological Survey Open-File Map, scale 1:24,000.

- 1970b, Preliminary geologic map and cross section of the Maple Peak Quadrangle and adjacent part of the Sabie Mountain Quadrangle, Juab County, Utah: U.S. Geological Survey Open-File Map, scale 1:24,000.

Morris, H. T., and Lovering, T. S., 1961, Stratigraphy of the East Tintic Mountains, Utah: U.S. Geological Survey Professional Paper $361,145 \mathrm{p}$.

Muessig, S. J., 1951, Geology of a part of Long Ridge, Utah [Ph.D. thesis]: Columbus, Ohio State University, $213 \mathrm{p}$.

Nelson, R. B., 1966, Structural development of the northernmost Snake Range, Kern Mountains, and Deep Creek Range, Nevada and
Utah: American Association of Petroleum Geologists Bulletin, v. 50, p. 921-951.

- 1969, Relation and history of structures in a sedimentary succession with deeper metamorphic structures, eastern Great Basin American Association of Petroleum Geologists Bulletin, v. 53, p. 307-339.

Nolan, T. B., 1935, The Gold Hill Mining District, Utah: U.S. Geological Survey Professional Paper 177, $172 \mathrm{p}$

Ojakangas, R. W., and Matsch, C. L., 1980, Upper Precambrian (Eocambrian) Mineral Fork Tillite of Utah: A continental glacial and glaciomarine sequence: Geological Society of America Bulletin, v. 91, p. 495-501.

Pitman, W. C., III, 1978, Relationship between eustacy and stratigraphic sequences of passive margins: Geological Society of America Bulletin, v. 89, p. 1389-1403.

Smith, C. V., 1956, Geology of the North Canyon area, southern Wasatch Mountains, Utah: Brigham Young University Research Studies, v. 3, no. 7, 32 p.

Sorensen, M. L., and Crittenden, M. D., Jr. 1976, Preliminary geologic map of the Mantua Quadrangle and part of the Willard Quadrangle, Box Elder, Weber, and Cache Counties, Utah: U.S. Geological Survey Map MF-720, scale $1: 24,000$.

Staatz, M. H., and Carr, W. J., 1964, Geology and mineral deposits of the Thomas and Dugway Ranges, Juab and Tooele Counties, Utah: U.S. Geological Survey Professional Paper 415, $188 \mathrm{p}$.

Stewart, J. H., 1974, Correlation of uppermost Precambrian and Lower Cambrian strata from southern to east-central Nevada: U.S. Geological Survey Journal of Research, v. 2, no. 5 , p. 609-618.

Stringham, B. F., 1942, Mineralization in the West Tintic Mining District, Utah: Geological Society of America Bulletin, v. 53 , p. $267-290$

Trimble, D. E., 1976, Geology of the Michaud and Pocatello Quadrangles, Bannock and Power Counties, Idaho: U.S. Geological Survey Bulletin 1400, 88 p.

Van Alstine, D. R., and Gillett, S. L., 1979, Paleomagnetism of upper Precambrian sed- imentary rocks from the Desert Range, Nevada: Journal of Geophysical Research, v. 84, no. B9, p. $4490-4500$.

Whitebread, D. H., 1969, Geologic map of the Wheeler Peak and Garrison Quadrangles, Nevada and Utah: U.S. Geological Survey Miscellaneous Geological Investigations Map 1-578, scale 1:48,000.

Woodward, L. A., 1963, Late Precambrian metasedimentary rocks of Egan Range, Nevada: American Association of Petroleum Geologists Bulletin, v. 47, p. 814-822.

- 1965, Late Precambrian stratigraphy of northern Deep Creek Range, Utah: American Association of Petroleum Geologists Bulletin, v. 49, p. 310-316.

- 1967, Stratigraphy and correlation of late Precambrian rocks of Pilot Range, Elko County, Nevada, and Box Elder County, Utah: American Association of Petroleum Geologists Bulletin, v. 5I, p. 235-243.

- 1968, Lower Cambrian and upper Precambrian strata of Beaver Mountains, Utah: American Association of Petroleum Geologists Bulletin, v. 52, p. 1279-1290.

_- 1972, Upper Precambrian stratigraphy of central Utah, in Baer, J. L., and Callaghan, E., eds., Plateau-Basin and Range transition zone, central Utah: Utah Geological Association Publication 2, p. 1-5.

1976, Stratigraphy of younger Precambrian rocks along Cordilleran hingeline, Utah and southern Idaho, in Hill, J. G., ed., Geology of the Cordilleran hingeline: Rocky Mountain Association of Geologists Symposium, p. 83-90.

Young, J. C., 1960, Structure and stratigraphy in north-central Schell Creek Range, in Geology of east-central Nevada: Intermountain Association of Petroleum Geologists, 11 th Annual Field Conference, Guidebook, p. $158-172$.

Manuscript Received by the Society JANUARY 29, 1981

Revised Manuscript Received June 30, 1981

MANUSCRIPT ACCEPTED AUGUST 11,1981 